Article

\title{
Molecular-Level Understanding of Selectively Photocatalytic Degradation of Ammonia via Copper Ferrite/N-Doped Graphene Catalyst under Visible Near-Infrared Irradiation
}

\author{
Hang Zhang, Yang Zhou, Shou-Qing Liu * , Qin-Qin Gu, Ze-Da Meng and Li Luo * \\ Jiangsu Key Laboratory of Environmental Functional Materials, School of Chemistry, \\ Biology and Material Engineering, Suzhou University of Science and Technology, Suzhou 215009, China; \\ zhang_hang@post.usts.edu.cn (H.Z.); zycalifornia@163.com (Y.Z.); qinqin_gu@post.usts.edu.cn (Q.-Q.G.); \\ compelitely@163.com (Z.-D.M.) \\ * Correspondence: shouqing_liu@hotmail.com (S.-Q.L.); luolichem08@163.com (L.L.); \\ Tel.: +86-512-6841-5070 (S.-Q.L.)
}

Received: 18 August 2018; Accepted: 15 September 2018; Published: 20 September 2018

check for updates

\begin{abstract}
Developing photocatalysts with molecular recognition function is very interesting and desired for specific applications in the environmental field. Copper ferrite/ $\mathrm{N}$-doped graphene $\left(\mathrm{CuFe}_{2} \mathrm{O}_{4} / \mathrm{NG}\right)$ hybrid catalyst was synthesized and characterized by surface photovoltage spectroscopy, X-ray powder diffraction, transmission electron microscopy, Raman spectroscopy, UV-Vis near-infrared diffuse reflectance spectroscopy and X-ray photoelectron spectroscopy. The $\mathrm{CuFe}_{2} \mathrm{O}_{4} / \mathrm{NG}$ catalyst can recognize ammonia from rhodamine $\mathrm{B}(\mathrm{RhB})$ in ammonia-RhB mixed solution and selectively degrade ammonia under visible near-infrared irradiation. The degradation ratio for ammonia reached $92.6 \%$ at $6 \mathrm{~h}$ while the degradation ratio for $\mathrm{RhB}$ was only $39.3 \%$ in a mixed solution containing $100.0 \mathrm{mg} / \mathrm{L} \mathrm{NH}_{3}-\mathrm{N}$ and $50 \mathrm{mg} / \mathrm{L} \mathrm{RhB}$. Raman spectra and X-ray photoelectron spectra indicated ammonia adsorbed on $\mathrm{CuFe}_{2} \mathrm{O}_{4}$ while $\mathrm{RhB}$ was adsorbed on NG. The products of oxidized ammonia were detected by gas chromatography, and results showed that $\mathrm{N}_{2}$ was formed during photocatalytic oxidization. Mechanism studies showed that photo-generated electrons flow to $\mathrm{N}$-doped graphene following the Z-scheme configuration to reduce $\mathrm{O}_{2}$ dissolved in solution, while photo-generated holes oxidize directly ammonia to nitrogen gas.
\end{abstract}

Keywords: molecular recognition; selective photocatalysis; N-doped graphene; copper ferrite; Z-scheme configuration; Ammonia

\section{Introduction}

The selectively photocatalytic oxidization of specific pollutants in practical multicomponent systems such as waters contaminated by organics and ammonia is of significance for the removal of specific pollutants. The World Health Organization recommends that the total amount of ammonia $\left(\mathrm{NH}_{3}\right)$ in drinking water should not exceed $1.5 \mathrm{mg} / \mathrm{L}$ [1]. Therefore, the development of the photocatalysts with the specific response to $\mathrm{NH}_{3}$ is very vital for the removal of ammonia in water treatments, which involves the molecular recognition to $\mathrm{NH}_{3}$.

$\mathrm{CuFe}_{2} \mathrm{O}_{4}$ is an interesting material with the band gap of $1.7 \mathrm{eV}$ due to its unique electronic configuration of valence shell $\left(\mathrm{Cu} 3 \mathrm{~d}^{10} 4 \mathrm{~s}^{1}\right)$ [1]. It has been widely applied in magnetic memory, high-frequency devices, sensors, drug delivery, anode materials, and catalysts owing to its advantages of environmental benignity, moisture insensitive, high dispersion, high reactivity, low price, large abundance of $\mathrm{Cu}$ and easy separation with an external magnet [2-5]. $\mathrm{CuFe}_{2} \mathrm{O}_{4}$ was coupled 
to graphene [6], $\mathrm{TiO}_{2}$ [7], $\mathrm{AgBr}$ [8] and $\mathrm{Ag}_{3} \mathrm{PO}_{4}$ [9] to fabricate composites for degrading organic pollutants. Wang and co-workers utilized $\mathrm{CuFe}_{2} \mathrm{O}_{4}$ as a photocatalyst to selectively degrade methylene blue in the presence of methylene orange, rhodamine $B$ and rhodamine $6 \mathrm{G}$, and the authors attributed the selective degradation to the specific interaction of active sites of catalyst with the methylene blue molecule [10]. To the best of our knowledge, however, the coupling of $\mathrm{CuFe}_{2} \mathrm{O}_{4}$ to nitrogen-doped graphene (NG) for the selective photocatalytic oxidization of $\mathrm{NH}_{3}$ has not been reported.

Graphene is a two-dimensional sp2-hybridized carbon material with unique properties such as excellent charge transport, outstanding transparency, huge specific surface area, high mechanical strength and superior thermal conductivity, so it was often used as a co-catalyst [11-17]. Moreover, molecular tailoring (nitrogen atoms were doped into graphene framework) can module its intrinsic properties to meet the rapidly increasing demand for practical applications in various fields. For example, nitrogen doping can tailor its electrical properties, open a band gap and allow it to show semiconducting properties. As a result, nitrogen doping can significantly improve the catalytic activity toward photocatalytic reactions due to the enhanced electron transportation from semiconductors to NG and the reduced recombination of the photogenerated electron-hole pairs [18-20]. In the work, we coupled $\mathrm{CuFe}_{2} \mathrm{O}_{4}$ to $\mathrm{NG}$ to prepare $\mathrm{CuFe}_{2} \mathrm{O}_{4} / \mathrm{NG}$ hybrid catalyst, it is expected that the $\mathrm{Cu}$-based hybrid catalyst can recognize ammonia via coordination effect since the formation constant of $\mathrm{Cu}\left(\mathrm{NH}_{3}\right)_{4}{ }^{2+}$ approached $1.1 \times 10^{13}$. This large constant implies a strong trend to form a complex between $\mathrm{NH}_{3}$ molecules and $\mathrm{Cu}$ sites, and also capturing capacity of $\mathrm{NH}_{3}$ from aqueous solutions.

\section{Results and Discussion}

\subsection{X-ray Photoelectron Spectroscopic Characterization}

X-ray photoelectron spectroscopic (XPS) determination indicated the as-prepared NG sample is composed of $\mathrm{C}, \mathrm{N}$ and $\mathrm{O}$ elements (Figure 1A), in which $\mathrm{C} 1 \mathrm{~s}, \mathrm{~N}$ 1s and $\mathrm{O}$ 1s peaks appeared at $\sim 284.6,400.0$ and $534.0 \mathrm{eV}$, respectively. The percentages of $\mathrm{C}, \mathrm{N}$ and $\mathrm{O}$ atoms are $83.24 \%, 7.84 \%$ and $8.92 \%$ in NG, respectively. The high-resolution XPS spectra of N, C, and O elements revealed the presence of the $\mathrm{N} 1 \mathrm{~s}$ peaks at $398.7,399.9$, and $401.9 \mathrm{eV}$, which corresponded to the pyridinic, pyrrolic, and graphitic nitrogen atoms, respectively [21-23]. The pyridinic and pyrrolic nitrogen atoms are bonded with two carbon atoms and donate one or two p-electron to the aromatic $\pi$-system. Graphitic nitrogen, also called "quaternary nitrogen", indicates that nitrogen atoms have substituted the carbon atoms in graphene layers [24]. The further studies showed the percentage of pyridinic, pyrrolic, and graphitic nitrogen atoms was $25.06 \%, 68.84 \%$ and $6.10 \%$, respectively, which is consistent with those reported [25,26]. The atom ratios of copper to iron in both pure $\mathrm{CuFe}_{2} \mathrm{O}_{4}$ and $\mathrm{CuFe}_{2} \mathrm{O}_{4} / \mathrm{NG}$ samples were also determined, the results are 1:2.17 and 1:2.31, respectively, indicating very close to the $1: 2$ stoichiometry.
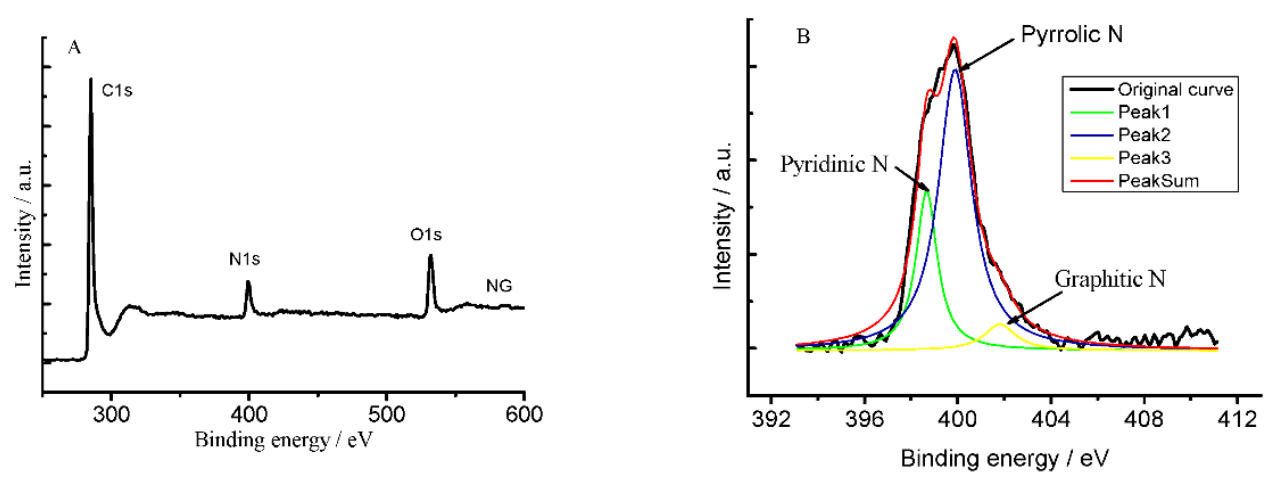

Figure 1. A wide-scan XPS spectrum of as-synthesized NG sample (A) and the high-resolution spectrum of $\mathrm{N} 1 \mathrm{~s}$ in NG sample (B). 


\subsection{X-ray Powder Diffraction Characterization}

Figure 2 presented the X-ray powder diffraction (XRD) patterns of the as-prepared $\mathrm{CuFe}_{2} \mathrm{O}_{4} / \mathrm{NG}$, $\mathrm{CuFe}_{2} \mathrm{O}_{4}$ and NG samples, with $\mathrm{CuFe}_{2} \mathrm{O}_{4}$ exhibiting the typical peaks of spinel ferrites with five prominent peaks occurring at $2 \theta=30.28^{\circ}, 35.75^{\circ}, 57.80^{\circ}$ and $62.83^{\circ}$. These diffraction peaks are indexed to Bragg planes (220), (311), (511) and (440), respectively. $\mathrm{CuFe}_{2} \mathrm{O}_{4}$ is the major crystal phase, which is in good agreement with JCPDS 25-0283 for the cubic spinel $\mathrm{CuFe}_{2} \mathrm{O}_{4}[27,28]$. Peaks at $2 \theta=32.90^{\circ}$ [plane 110] and $39.11^{\circ}$ [plane 111] suggests a small fraction of $\mathrm{CuO}$. The diffraction peak at $26.43^{\circ}$ is indexed to Bragg plane (002) assigned to $\mathrm{N}$-doped graphene. The peak at $30.28^{\circ}$ from the $\mathrm{CuFe}_{2} \mathrm{O}_{4} / \mathrm{NG}$ sample, as seen in curve a in Figure 2, is attributed to plane (220) of $\mathrm{CuFe}_{2} \mathrm{O}_{4}[29,30]$. But, the peak did not appear in the single $\mathrm{CuFe}_{2} \mathrm{O}_{4}$ sample. It showed that $\mathrm{NG}$ component makes $\mathrm{CuFe}_{2} \mathrm{O}_{4}$ more regular. In addition, plane (002) assigned to $\mathrm{N}$-doped graphene did not appear in the $\mathrm{CuFe}_{2} \mathrm{O}_{4} / \mathrm{NG}$ sample, because the amount of $\mathrm{NG}$ is very small in the $\mathrm{CuFe}_{2} \mathrm{O}_{4} / \mathrm{NG}$ sample. The average diameters (D) of the as-prepared $\mathrm{CuFe}_{2} \mathrm{O}_{4}$ and $\mathrm{CuFe}_{2} \mathrm{O}_{4} / \mathrm{NG}$ crystal sizes are 12.1 and $14.5 \mathrm{~nm}$, respectively, which were determined using the Scherrer equation $\mathrm{D}=\mathrm{K} \lambda /(\mathrm{W} \cos \theta)$ at a diffraction angle of $35.75^{\circ}(2 \theta)$. The average size of $\mathrm{CuFe}_{2} \mathrm{O}_{4} / \mathrm{NG}$ crystals is enlarged by the surface self-assembly of $\mathrm{Cu}^{2+}$ or $\mathrm{Fe}^{3+}$ ions on NG sheets.

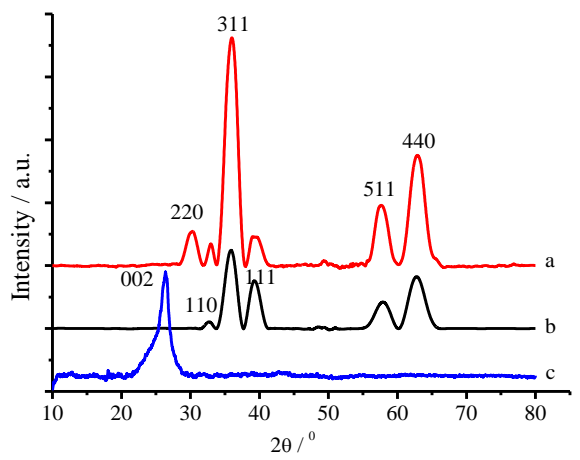

Figure 2. XRD patterns of the as-prepared $\mathrm{CuFe}_{2} \mathrm{O}_{4} / \mathrm{NG}(\mathbf{a}), \mathrm{CuFe}_{2} \mathrm{O}_{4}(\mathbf{b})$ and $\mathrm{NG}$ (c) samples.

\subsection{Transimission Electron Microscope Characterization}

Figure $3 \mathrm{~A}, \mathrm{~B}$ showed that the $\mathrm{CuFe}_{2} \mathrm{O}_{4}$ particles were dispersed on a layered structure of NG sheets. The high-resolution transmission electron microscopy (HRTEM) image displayed the lattice fringes. The d-spacing value between the adjacent lattice fringes is $0.25 \mathrm{~nm}$ (Figure 3C), which is characteristic of (211) spinel planes [27,28]. The size of $\mathrm{CuFe}_{2} \mathrm{O}_{4}$ crystals looked uniform; the diameter of most crystal particles is distributed about $25-30 \mathrm{~nm}$, which is in the scope of the average particle size of $\mathrm{CuFe}_{2} \mathrm{O}_{4}$ crystals that was estimated by XRD.
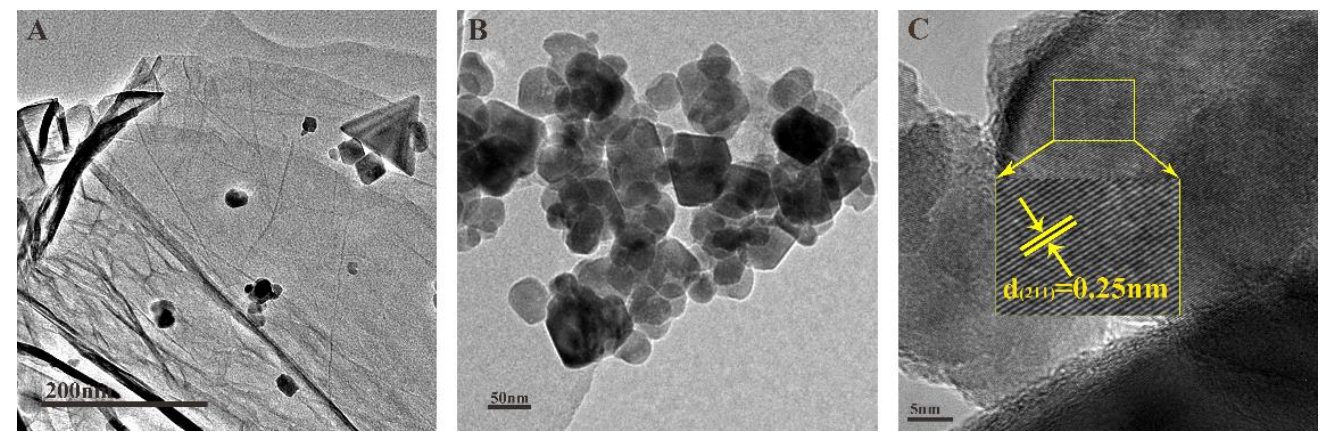

Figure 3. TEM image of $\mathrm{CuFe}_{2} \mathrm{O}_{4} / \mathrm{NG}$ samples (A,B) and HRTEM image of $\mathrm{CuFe}_{2} \mathrm{O}_{4} / \mathrm{NG}$ sample (C). 


\subsection{Ultraviolet-Visible Near-Infrared Diffuse Reflectance Spectroscopy}

UV-visible near-infrared diffuse reflectance spectra were measured to elucidate the enhanced photocatalytic activity of the $\mathrm{CuFe}_{2} \mathrm{O}_{4} / \mathrm{NG}$ hybrid catalyst. Compared with curve $\mathrm{b}\left(\mathrm{CuFe}_{2} \mathrm{O}_{4}\right)$ in Figure 4, curve a $\left(\mathrm{CuFe}_{2} \mathrm{O}_{4} / \mathrm{NG}\right)$ underwent a red-shift, indicating the $\mathrm{CuFe}_{2} \mathrm{O}_{4} / \mathrm{NG}$ hybrid catalyst can harvest more incident light energy.

Two Tauc-curves of the $\mathrm{CuFe}_{2} \mathrm{O}_{4} / \mathrm{NG}$ and $\mathrm{CuFe}_{2} \mathrm{O}_{4}$ catalysts for the direct transition were obtained using transformation data from Figure 4 and are presented in Figure 5, respectively. Extrapolation of linear portions of the curves towards absorbance axis to zero $(y=0)$ gave a band gap $\left(\mathrm{E}_{\mathrm{g}}\right)$ of direct transitions. The direct band gap estimated for the $\mathrm{CuFe}_{2} \mathrm{O}_{4}$ sample is equal to $1.70 \mathrm{eV}$, which is in very good agreement with that reported [31]. As expected, the band gap for the $\mathrm{CuFe}_{2} \mathrm{O}_{4} / \mathrm{NG}$ sample shifted to $1.50 \mathrm{eV}$, the red-shift of $0.20 \mathrm{eV}$ exhibited a strong electron-orbital interaction between NG and $\mathrm{CuFe}_{2} \mathrm{O}_{4}$ and a widened absorption scope of solar irradiation. In fact, the absorption edge for the $\mathrm{CuFe}_{2} \mathrm{O}_{4} / \mathrm{NG}$ composite catalyst was extended to $870 \mathrm{~nm}$ as indicated in curve a in Figure 4 . This wavelength falls in the scope of near-infrared light irradiation, which revealed the $\mathrm{CuFe}_{2} \mathrm{O}_{4} / \mathrm{NG}$ composite catalyst can utilize near-infrared irradiation for photocatalysis.

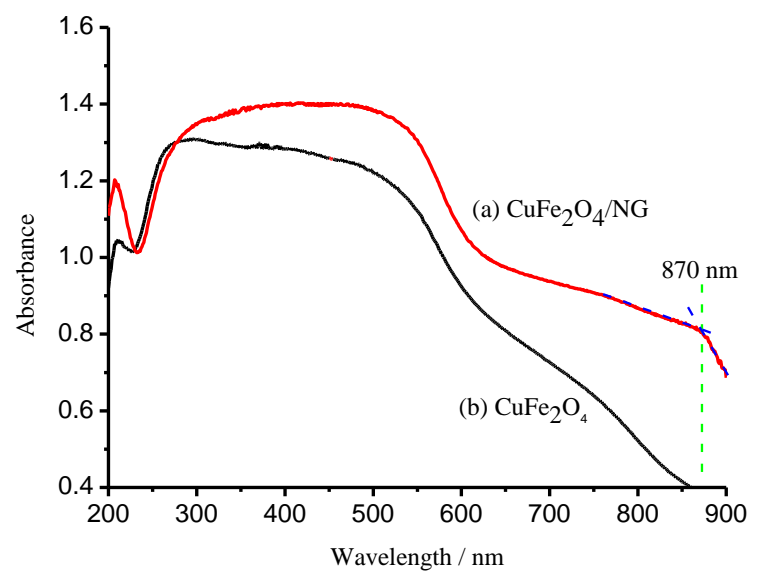

Figure 4. UV-visible near-infrared diffuse reflectance spectra of $\mathrm{CuFe}_{2} \mathrm{O}_{4} / \mathrm{NG}(\mathbf{a}), \mathrm{CuFe}_{2} \mathrm{O}_{4}(\mathbf{b})$ catalysts.

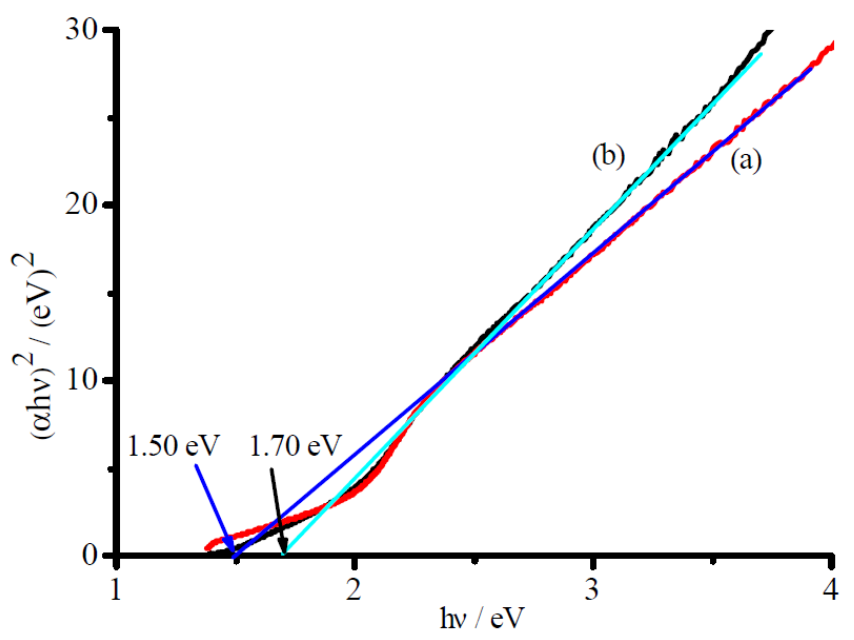

Figure 5. Tauc-plots for direct transition of $\mathrm{CuFe}_{2} \mathrm{O}_{4} / \mathrm{NG}(\mathbf{a}), \mathrm{CuFe}_{2} \mathrm{O}_{4}(\mathbf{b})$ catalysts.

\subsection{Molecular Recognition and Selective Photocatalysis}

Figure 6 presented the separate degradation of ammonia and $\mathrm{RhB}$ using $\mathrm{CuFe}_{2} \mathrm{O}_{4} / \mathrm{NG}$ as the photocatalyst under visible near-infrared irradiation. The degradation ratios of $96.3 \%$ for ammonia and of $63.6 \%$ for RhB were achieved, respectively, at $5 \mathrm{~h}$ under visible-near-infrared irradiation in 
$100 \mathrm{mg} / \mathrm{L}$ ammonia solution alone and $50 \mathrm{mg} / \mathrm{L} \mathrm{RhB}$ solution alone (for the blank or controlled tests, see Figure S1 in Supplementary Materials). The facts show that the photocatalyst can degrade both ammonia and $\mathrm{RhB}$ in a single-component solution. The degradation for organic pollutants is consistent with the references reported by $\mathrm{Qu}$ and Wang [32,33]. In a mixture of ammonia and RhB with the same concentration of ammonia and $\mathrm{RhB}$ as that in Figure 6, however, the degradation ratio for ammonia reached $92.6 \%$ at $6 \mathrm{~h}$ whereas the degradation ratio for $\mathrm{RhB}$ decreased to $39.3 \%$ as shown in Figure 7 . The high degradation ratio for ammonia but low one for $\mathrm{RhB}$ in the mixed solution confirms the $\mathrm{CuFe}_{2} \mathrm{O}_{4} / \mathrm{NG}$ photocatalyst prefers to degrade ammonia in mixed solution containing ammonia and organic compounds under visible near-infrared irradiation. The phenomenon also occurred between ammonia and methyl orange. The preference indicates that the $\mathrm{CuFe}_{2} \mathrm{O}_{4} / \mathrm{NG}$ photocatalyst can selectively eliminate ammonia.

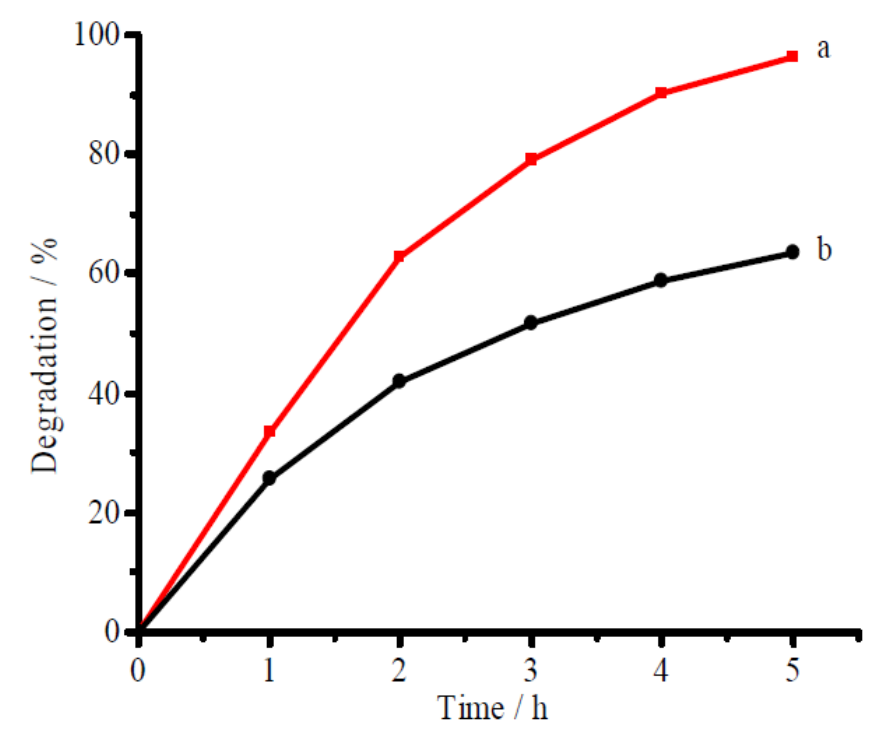

Figure 6. Photocatalytic degradation of ammonia (a) and $\mathrm{RhB}(\mathbf{b})$ in $100 \mathrm{mg} / \mathrm{L}$ ammonia-N solution alone and in $50 \mathrm{mg} / \mathrm{L} \mathrm{RhB}$ solution alone, respectively. The $\mathrm{CuFe}_{2} \mathrm{O}_{4} / \mathrm{NG}$ catalyst of $0.1 \mathrm{~g}$ was used in $50 \mathrm{~mL}$ volume with $\mathrm{pH} 9.5$ under visible light irradiation.

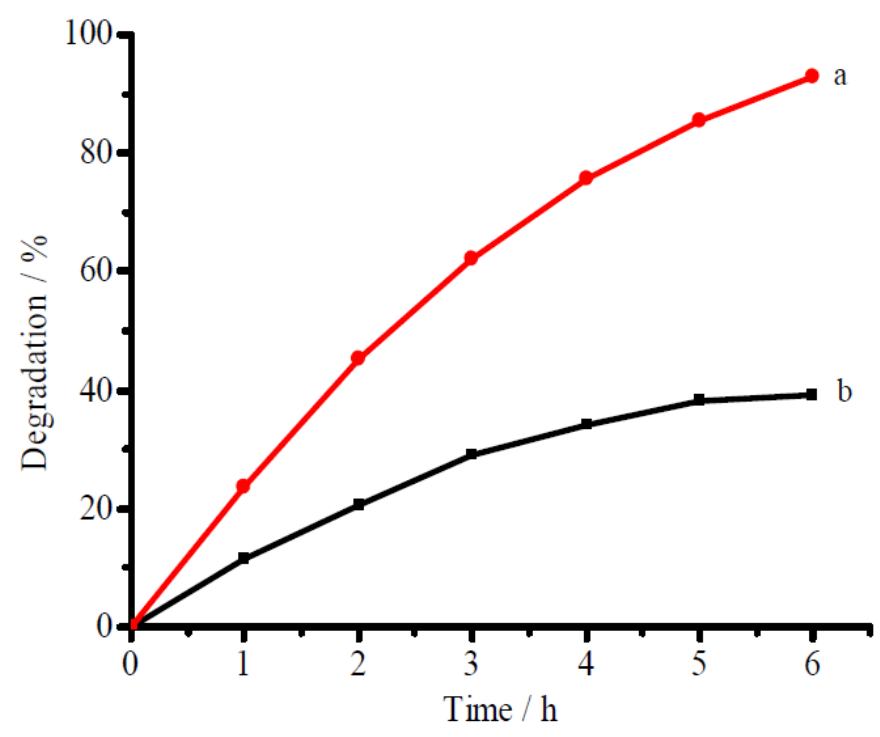

Figure 7. Selective degradation of ammonia (a) and $\mathrm{RhB}(\mathbf{b})$ in a mixed solution containing $100 \mathrm{mg} / \mathrm{L}$ ammonia-N plus $50 \mathrm{mg} / \mathrm{L} \mathrm{RhB}$. The other conditions are the same as those in Figure 6. 


\subsection{Effect of NG Content}

In order to obtain the optimal degradation conditions, the mass ratio of $\mathrm{NG}$ to $\mathrm{CuFe}_{2} \mathrm{O}_{4}$ was optimized, the results were shown in Figure 8 (see detailed information in Figure S2 in Supplementary Materials), the mass percentage of $6 \%$ for $\mathrm{NG}$ to $\mathrm{CuFe}_{2} \mathrm{O}_{4}$ resulted in an optimal degradation ratio $(96.3 \%)$ at $5 \mathrm{~h}$. Comparative studies showed that the $\mathrm{CuFe}_{2} \mathrm{O}_{4} / \mathrm{NG}$ catalyst possessed the highest activity for ammonia, compared with those of the $\mathrm{CuFe}_{2} \mathrm{O}_{4}$ and $\mathrm{CuFe}_{2} \mathrm{O}_{4} / \mathrm{rGO}$ catalysts (see Figure S3 in Supplementary Materials). Therefore, NG can enhance the photocatalytic activity of $\mathrm{CuFe}_{2} \mathrm{O}_{4}$.

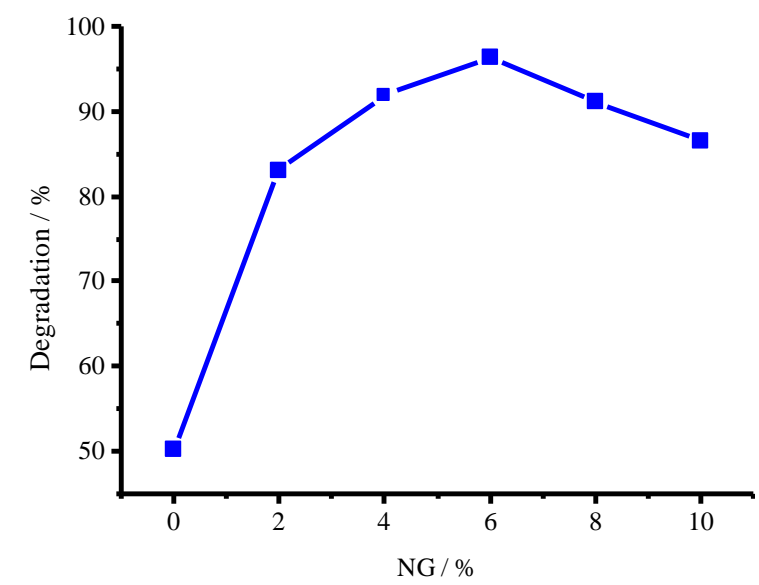

Figure 8. Dependence of photocatalytic activity for the as-prepared $\mathrm{CuFe}_{2} \mathrm{O}_{4} / \mathrm{NG}$ photocatalyst on NG percentage.

\subsection{Degradation Kinetics}

The different initial concentrations of ammonia were used as desired while the dosage of $0.1 \mathrm{~g}$ catalyst in $50.0 \mathrm{~mL}$ solution with $\mathrm{pH} 9.5$ was kept constant. The degradation kinetic curves for the various ammonia concentrations were shown in Figure 9 . The parameter $\ln \left(C_{0} / C_{t}\right)$ is linearly proportional to the irradiation time $t$, following a pseudo-first order kinetic equation

$$
\ln \left(\mathrm{C}_{0} / \mathrm{C}_{\mathrm{t}}\right)=\mathrm{K}_{\mathrm{app}} \mathrm{t}+\mathrm{b}
$$

The average value of the apparent rate constant $k_{a p p}$ can be estimated as $0.3224 \mathrm{~h}^{-1}$, the standard error is equal to 0.01278 .

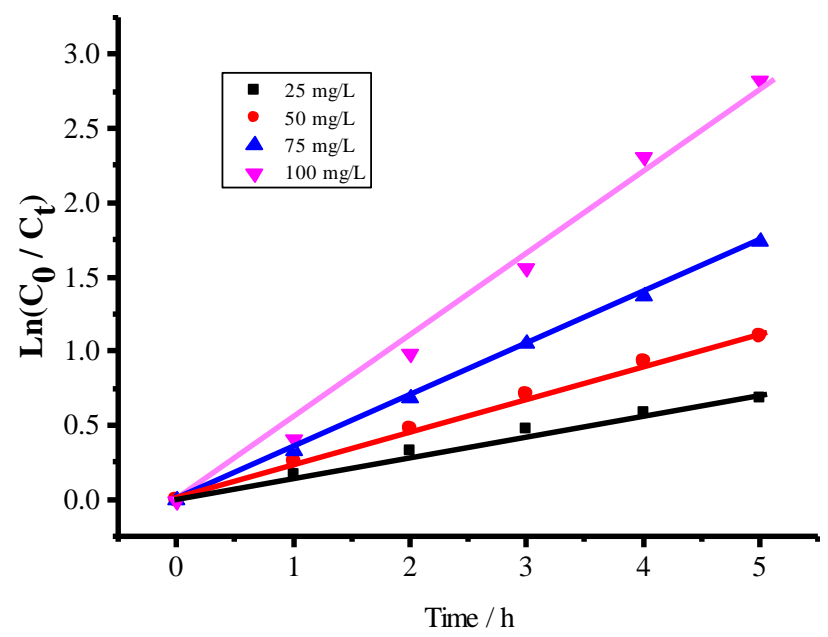

Figure 9. Dependence of $\ln \left(C_{0} / C_{t}\right)$ on irradiation time in $50 \mathrm{~mL}$ solutions at $\mathrm{pH} 9.5$ during the photocatalytic degradation of ammonia at different concentrations of 25,50,75, $100 \mathrm{mg} / \mathrm{L}$ with $0.1 \mathrm{~g}$ $\mathrm{CuFe}_{2} \mathrm{O}_{4} / \mathrm{NG}$ catalyst. 


\subsection{Stability of $\mathrm{CuFe}_{2} \mathrm{O}_{4} / \mathrm{NG}$ Catalyst}

The cyclic tests were performed in order to evaluate the catalytic stability during a series of experiments. The catalyst of $0.1 \mathrm{~g} \mathrm{CuFe}_{2} \mathrm{O}_{4} / \mathrm{NG}$ was tested in six consecutive experiments using the fresh ammonia solutions. The reaction time was about $5 \mathrm{~h}$ for each run. At the end of the previous experiment, the catalyst was collected using an external magnetite, and then separated and washed with deionized water for three times. It was observed that the sixth photocatalytic degradation ratio of ammonia using the same $\mathrm{CuFe}_{2} \mathrm{O}_{4} / \mathrm{NG}$ catalyst still achieved $92 \%$ (Figure 10), showing the $\mathrm{CuFe}_{2} \mathrm{O}_{4} / \mathrm{NG}$ catalyst is very stable. The spent catalyst was taken out after 6 runs and it was measured by TEM to confirm the stability. As seen in Figure S4 in Supplementary Materials, the nanoparticles were still distributed on NG sheets, the d-spacing value of $0.25 \mathrm{~nm}$ indicated that the adjacent lattice fringes of (211) spinel planes remained.

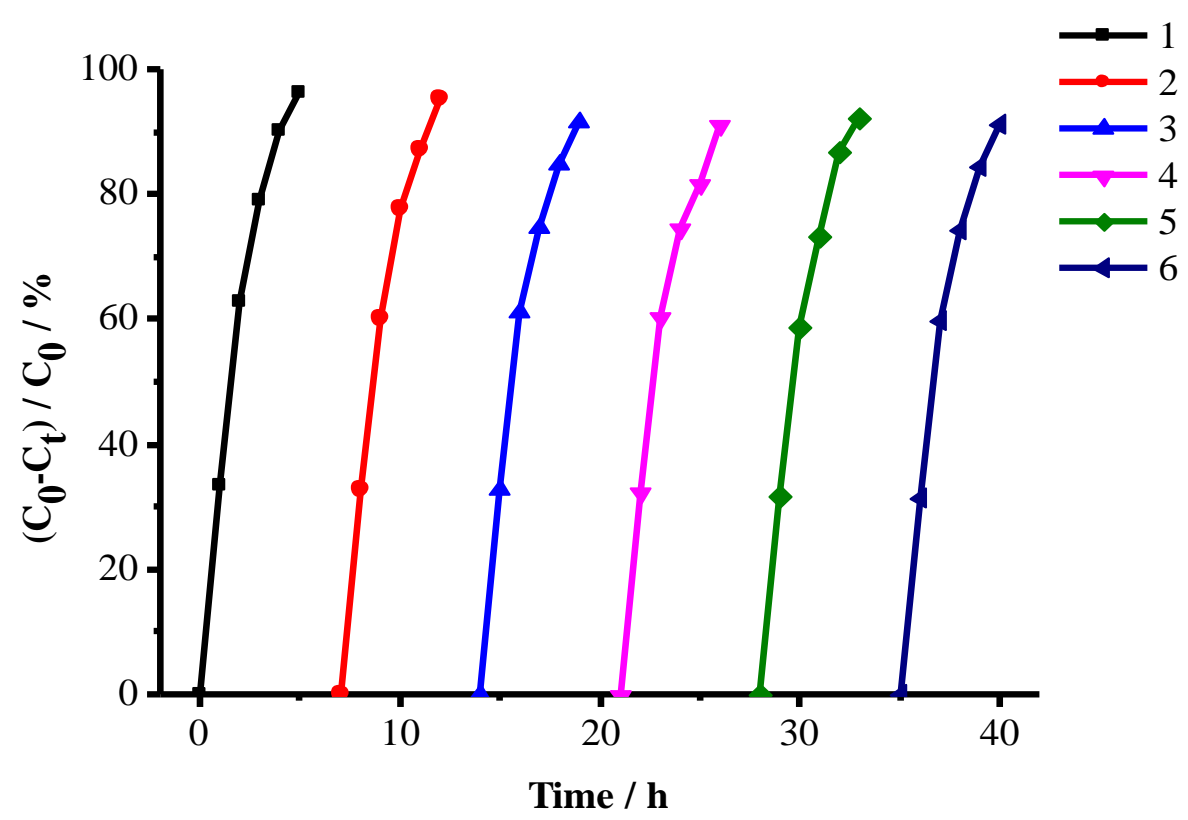

Figure 10. Cyclic tests for checking $\mathrm{CuFe}_{2} \mathrm{O}_{4} / \mathrm{NG}$ stability. The volume of the test solutions is $50 \mathrm{~mL}$, which contained $100 \mathrm{mg} / \mathrm{L}$ ammonia-nitrogen at $\mathrm{pH} 9.5$ under visible-near-infrared irradiation.

\subsection{Identification of Products}

According to Chio's and Butler's investigations [1,34], ammonia was oxidized into $\mathrm{N}_{2}$ and $\mathrm{NO}_{3}{ }^{-}\left(\mathrm{NO}_{2}{ }^{-}\right)$by two paths. One is through a series of $\mathrm{NH}_{2}, \mathrm{NH}, \mathrm{N}_{2} \mathrm{H}_{\mathrm{x}+\mathrm{y}(\mathrm{x}+\mathrm{y}=0,1,2)}$ intermediates, giving out $\mathrm{N}_{2}$ as a consequence. The other is to form the $\mathrm{HONH}_{2}$ and $\mathrm{NO}_{2}{ }^{-}$intermediates, finally generating $\mathrm{NO}_{3}{ }^{-} . \mathrm{NO}_{3}{ }^{-}$or $\mathrm{NO}_{2}{ }^{-}$ions will appear the absorption band in the wavelength range of 200 to $260 \mathrm{~nm}$ if there exists $\mathrm{NO}_{3}{ }^{-}$or $\mathrm{NO}_{2}{ }^{-}$in aqueous solution [33] (see Figures S5 and S6 in Supplementary Materials).

In our case the ultraviolet-visible spectroscopic measurements displayed that there is not any absorption band from $200 \mathrm{~nm}$ to $260 \mathrm{~nm}$ except noise wave during the photocatalytic process as shown in Figure 11, suggesting neither nitrite nor nitrate were formed during the degradation process since $\mathrm{NO}_{2}{ }^{-}$and $\mathrm{NO}_{3}{ }^{-}$can generate the absorption peaks at $211 \mathrm{~nm}$ and $206 \mathrm{~nm}$, respectively [34-36]. 


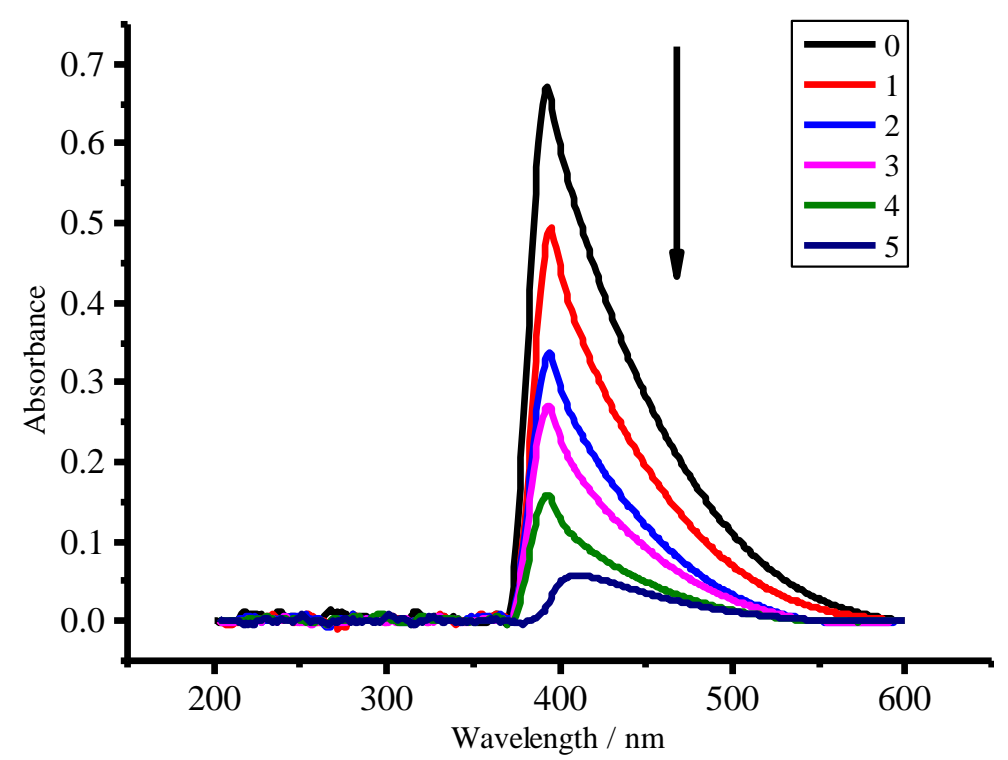

Figure 11. Ultraviolet-visible absorption spectra of ammonia solution during photocatalytic degradation process at $0,1,2,3,4,5 \mathrm{~h}$, respectively. Experimental conditions as follows: the concentration of ammonia-nitrogen, $100 \mathrm{mg} / \mathrm{L}$; catalyst mass of $\mathrm{CuFe}_{2} \mathrm{O}_{4} / \mathrm{NG}, 0.1 \mathrm{~g}$; solution volume: $50 \mathrm{~mL}$ with $\mathrm{pH} 9.5$.

In order to confirm the product of oxidized ammonia, the detection of nitrogen gas $\left(\mathrm{N}_{2}\right)$ was performed during the photocatalytic degradation of ammonia in the sealed photocatalytic reaction system mentioned previously, in which a $50 \mathrm{~mL}$ aqueous solution containing $100.0 \mathrm{mg} / \mathrm{L} \mathrm{NH}_{3}-\mathrm{N}$ was irradiated under visible-near-infrared light, the mixed gas of oxygen and argon was cycled, and the released $\mathrm{N}_{2}$ was detected with gas chromatograph. The results were displayed in Figure 12. During the visible-near-infrared light irradiation, the peak of $\mathrm{O}_{2}$ gas in the sealed reaction system was declining with irradiation time, while the peak of $\mathrm{N}_{2}$ gas was boosting with the irradiation time, indicating the generation of $\mathrm{N}_{2}$ gas during the photocatalytic decomposition of ammonia.

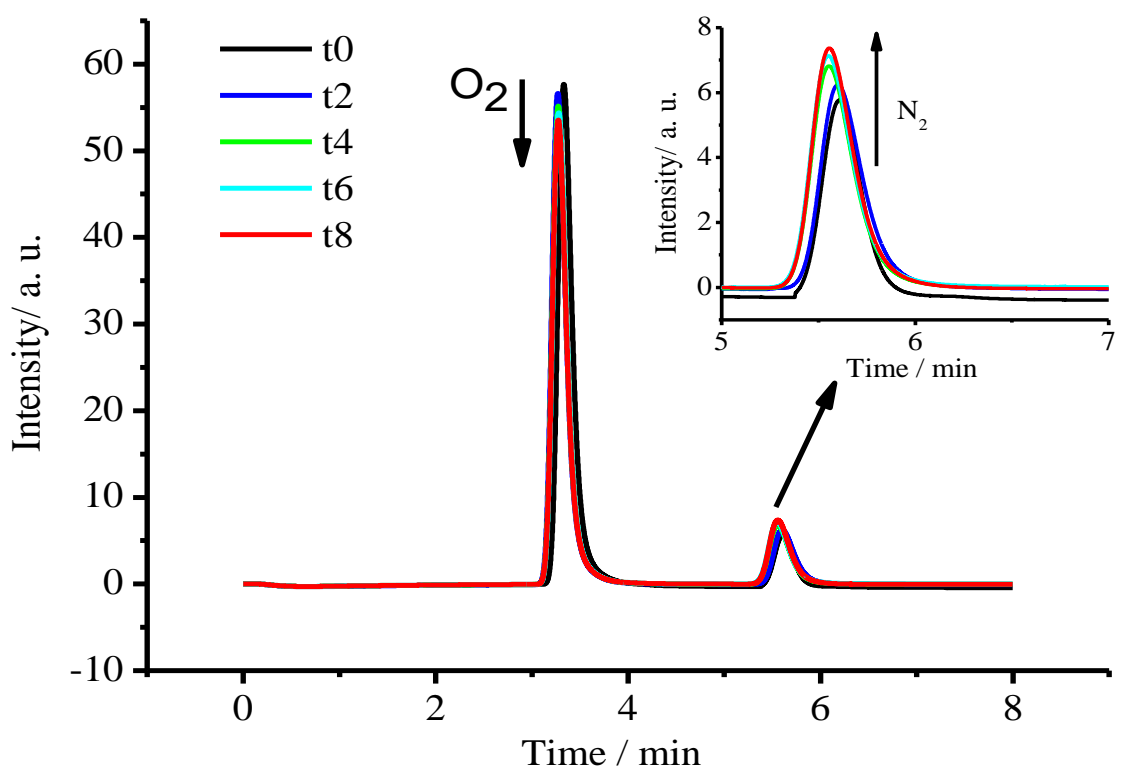

Figure 12. Gas chromatograms during the photocatalytic degradation of ammonia under visible near-infrared light irradiation at $\mathrm{t}=0.0,2.0,4.0,6.0$ and $8.0 \mathrm{~h}$, respectively. 


\subsection{Molecular Recognition Evidence}

In order to explore the mechanism for the selective degradation of ammonia, Raman spectroscopic measurements were performed before and after the $\mathrm{CuFe}_{2} \mathrm{O}_{4} / \mathrm{NG}$ catalyst was immersed in $\mathrm{NH}_{3}$ solution and $\mathrm{NH}_{3}-\mathrm{RhB}$ mixed solution, respectively. Figure 13 displayed the Raman spectra of the $\mathrm{CuFe}_{2} \mathrm{O}_{4} / \mathrm{NG}$ catalyst (a) itself and $\mathrm{NH}_{3}$ adsorbed on the $\mathrm{CuFe}_{2} \mathrm{O}_{4} / \mathrm{NG}$ catalyst (b) and both $\mathrm{NH}_{3}$ and $\mathrm{RhB}$ adsorbed on the $\mathrm{CuFe}_{2} \mathrm{O}_{4} / \mathrm{NG}$ catalyst (c). As to the assignments of the Raman shifts of the $\mathrm{CuFe}_{2} \mathrm{O}_{4}$ component in the composite catalyst, they were listed in Table 1 based on the $\mathrm{FeO}_{4}$ symmetry [37].

Besides the Raman peaks of $\mathrm{CuFe}_{2} \mathrm{O}_{4} / \mathrm{NG}$ itself, a new peak at $1100 \mathrm{~cm}^{-1}$ appeared in Raman spectra both (b) and (c) after the $\mathrm{CuFe}_{2} \mathrm{O}_{4} / \mathrm{NG}$ catalyst was immersed in $\mathrm{NH}_{3}$ solution and $\mathrm{NH}_{3}-\mathrm{RhB}$ mixed solution, respectively. This Raman shift at $1100 \mathrm{~cm}^{-1}$ was assigned to the bending vibration of $\mathrm{NH}_{3}-\mathrm{H}_{2} \mathrm{O}$ complex [38]. Thus, it unambiguously revealed that $\mathrm{NH}_{3}$ was adsorbed on the $\mathrm{CuFe}_{2} \mathrm{O}_{4} / \mathrm{NG}$ catalyst in both cases.

For RhB Raman shifts, it is known that the spontaneous Raman shift range of $\mathrm{RhB}$ is from 500 to $1700 \mathrm{~cm}^{-1}$ [39], thus, the shift at $602 \mathrm{~cm}^{-1}$ from Raman spectrum (c) in Figure 13 was attributed to the $C-C$ bending vibration of xanthene ring in the molecular structure of RhB $[40,41]$. For the NG component, there were two Raman shifts located at 1372 and $1580 \mathrm{~cm}^{-1}$ as seen in curves (a) and (b), respectively, which were attributed to $D$ (defect-induced mode) and $G$ (in-plane vibration mode) bands. The $G$ band $\left(1580 \mathrm{~cm}^{-1}\right)$ derived from the $G\left(1610 \mathrm{~cm}^{-1}\right)$ of the pristine graphene, which also confirmed that nitrogen atoms were incorporated into graphene framework $[42,43]$. Compared with curve (b), the significant shifts occurred of $\mathrm{D}$ and $\mathrm{G}$ bands after the $\mathrm{CuFe}_{2} \mathrm{O}_{4} / \mathrm{NG}$ catalyst was immersed in $\mathrm{NH}_{3}-\mathrm{RhB}$ mixed solution, as seen curve (c). The D and G bands were shifted from 1372 and $1580 \mathrm{~cm}^{-1}$ to 1308 and $1560 \mathrm{~cm}^{-1}$, respectively, which indicated the strong interaction between NG sheets and $\mathrm{RhB}$, thereby $\mathrm{RhB}$ being adsorbed on NG sheets. It is reasonable that the $\pi-\pi$ interaction between NG and RhB occurs because there are $\pi$ bonds in their planar aromatic moieties [44,45] (for RhB structure, see Figure S7 in Supplementary Materials). However, compared with curve (a) in Figure 13, no shift of the $\mathrm{D}$ and $\mathrm{G}$ bands appeared in curve (b) after the $\mathrm{CuFe}_{2} \mathrm{O}_{4} / \mathrm{NG}$ catalyst was immersed in the single $\mathrm{NH}_{3}$ component solution. It suggested that $\mathrm{NH}_{3}$ was adsorbed preferentially on $\mathrm{CuFe}_{2} \mathrm{O}_{4}$ moiety, but not NG, in the composite catalyst.

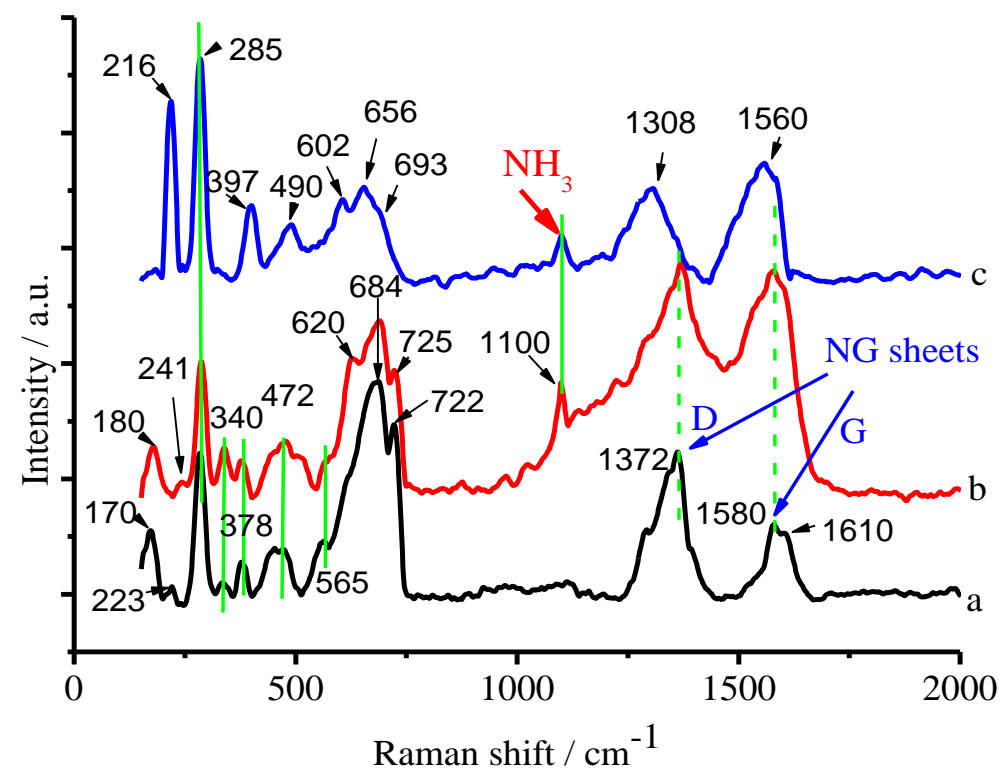

Figure 13. Raman spectra of the $\mathrm{CuFe}_{2} \mathrm{O}_{4} / \mathrm{NG}$ sample (a), the $\mathrm{CuFe}_{2} \mathrm{O}_{4} / \mathrm{NG}$ sample after being immersed in $100 \mathrm{mg} / \mathrm{L} \mathrm{NH}_{3}-\mathrm{N}$ solution for $4 \mathrm{~h} \mathrm{(b)}$ and the $\mathrm{CuFe}_{2} \mathrm{O}_{4} / \mathrm{NG}$ sample after being immersed in $100 \mathrm{mg} / \mathrm{L} \mathrm{NH}_{3}-\mathrm{N}$ and $50.0 \mathrm{mg} / \mathrm{L} \mathrm{RhB}$ mixed solution for $4 \mathrm{~h}$ (c). 
Table 1. Assignments of Raman shifts for $\mathrm{CuFe}_{2} \mathrm{O}_{4} / \mathrm{NG}$.

\begin{tabular}{ccccccccc}
\hline Mode & T (F2g) & T/L & v2 & v4 & v4 & v3 & v3 & v1 \\
\hline $\mathrm{a}^{*}$ & 170 & 223 & 285 & 378 & $452 \sim 472$ & 565 & 684 & 722 \\
$\mathrm{~b}$ & 180 & 241 & 285 & 378 & 472 & 565 & 684 & 725 \\
$\mathrm{c}$ & - & 216 & 285 & 397 & 489 & - & 656 & 693 \\
\hline
\end{tabular}

* (a), $\mathrm{CuFe}_{2} \mathrm{O}_{4} / \mathrm{NG}$; (b), $\mathrm{CuFe}_{2} \mathrm{O}_{4} / \mathrm{NG}$ after being immersed in $100 \mathrm{mg} / \mathrm{L} \mathrm{NH}_{3}$ solution; (c), $\mathrm{CuFe}_{2} \mathrm{O}_{4} / \mathrm{NG}$ after being immersed in $100 \mathrm{mg} / \mathrm{L} \mathrm{NH}_{3}$ and $50 \mathrm{mg} / \mathrm{L} \mathrm{RhB}$ mixed solution.

In order to confirm ammonia adsorbed on $\mathrm{CuFe}_{2} \mathrm{O}_{4}$, the single $\mathrm{CuFe}_{2} \mathrm{O}_{4}$ sample (to avoids interference of nitrogen from NG) was synthesized and immersed in $100 \mathrm{mg} / \mathrm{L} \mathrm{NH}_{3}-\mathrm{N}$ solution for $4 \mathrm{~h}$ for adsorption, then it was taken out and washed with deionized water for three times to remove ammonia adsorbed physically. Finally, it was dried at $60{ }^{\circ} \mathrm{C}$ in a vacuum chamber for XPS measurement. For the sake of contrast, other $\mathrm{CuFe}_{2} \mathrm{O}_{4}$ component that was not immersed in $\mathrm{NH}_{3}$ solution was also used for XPS measurement. Figure 14 displayed the high-resolution XPS spectrum of $\mathrm{N} 1 \mathrm{~s}$ in the $\mathrm{CuFe}_{2} \mathrm{O}_{4}$ sample after it was immersed in a $100 \mathrm{mg} / \mathrm{L} \mathrm{NH}_{3}-\mathrm{N}$ solution. It indicated evidently the presence of nitrogen atoms, whereas an $\mathrm{N}$ 1s peak was not detected out when the $\mathrm{CuFe}_{2} \mathrm{O}_{4}$ sample was not immersed in such $100 \mathrm{mg} / \mathrm{L} \mathrm{NH}_{3}-\mathrm{N}$ solution. The dissimilarity implies that ammonia was adsorbed on the $\mathrm{CuFe}_{2} \mathrm{O}_{4}$ sample when it was immersed in ammonia solution. Deconvolution of the XPS spectrum of $\mathrm{N}$ 1s may be ascribed to the Eb of $\mathrm{NH}_{3}(399.97 \mathrm{eV})$, copper- $\mathrm{NH}_{3}$ (398.30 eV) and $\mathrm{NO}_{2}{ }^{-}$[46], which implied ammonia is partly oxidized in air atmosphere.

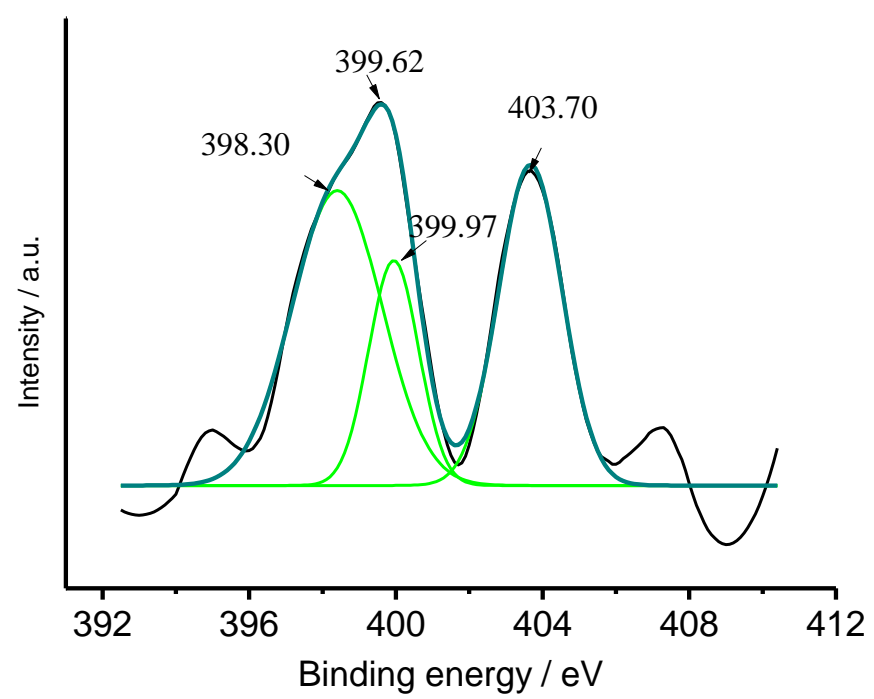

Figure 14. High-resolution XPS spectrum of $\mathrm{N}$ 1s on the $\mathrm{CuFe}_{2} \mathrm{O}_{4}$ sample after it was immersed in 100 $\mathrm{mg} / \mathrm{L} \mathrm{NH}_{3}-\mathrm{N}$ solution.

Furthermore, the coordination between $\mathrm{NH}_{3}$ and $\mathrm{Cu}$ (II) or Fe(III) was identified by XPS technique. The high-resolution XPS measurements of $\mathrm{Cu} 2 \mathrm{p}$ and $\mathrm{Fe} 2 \mathrm{p}$ in the $\mathrm{CuFe}_{2} \mathrm{O}_{4}$ sample were conducted as shown in Figures 15 and 16 before (a) and after (b) the $\mathrm{CuFe}_{2} \mathrm{O}_{4}$ sample was immersed in $100 \mathrm{mg} / \mathrm{L}$ $\mathrm{NH}_{3}-\mathrm{N}$ solution, respectively. Very interestingly, the shifts of Eb at $933.10 \mathrm{eV}$ for $\mathrm{Cu} 2 \mathrm{p} 3 / 2(0.75 \mathrm{eV})$ and at $953.06 \mathrm{eV}$ for $\mathrm{Cu} 2 \mathrm{p} 1 / 2(0.50 \mathrm{eV})$ were observed [47], implying that the chemical surroundings of copper in the $\mathrm{CuFe}_{2} \mathrm{O}_{4}$ sample were altered after it was immersed in $100 \mathrm{mg} / \mathrm{L} \mathrm{NH}_{3}-\mathrm{N}$ solution. However, the shifts of $\mathrm{Eb}$ at $710.56 \mathrm{eV}$ for $\mathrm{Fe} 2 \mathrm{p} \mathrm{3/2}$ and $\mathrm{Eb}$ at $724.10 \mathrm{eV}$ for $\mathrm{Fe} \mathrm{2p} \mathrm{1/2} \mathrm{were} \mathrm{not}$ observed as shown in Figure 15 [48]. It is well known that the formation constant of $\mathrm{Cu}\left(\mathrm{NH}_{3}\right)_{4}{ }^{2+}$ is up to $1.1 \times 10^{13}$. Thus, it is reasonable that the $\mathrm{CuFe}_{2} \mathrm{O}_{4} / \mathrm{NG}$ catalyst can recognize ammonia via a coordination effect between copper atoms in the catalyst and nitrogen atoms in ammonia; it is concluded that the coordination interaction occurred between copper, but not iron and ammonia. 


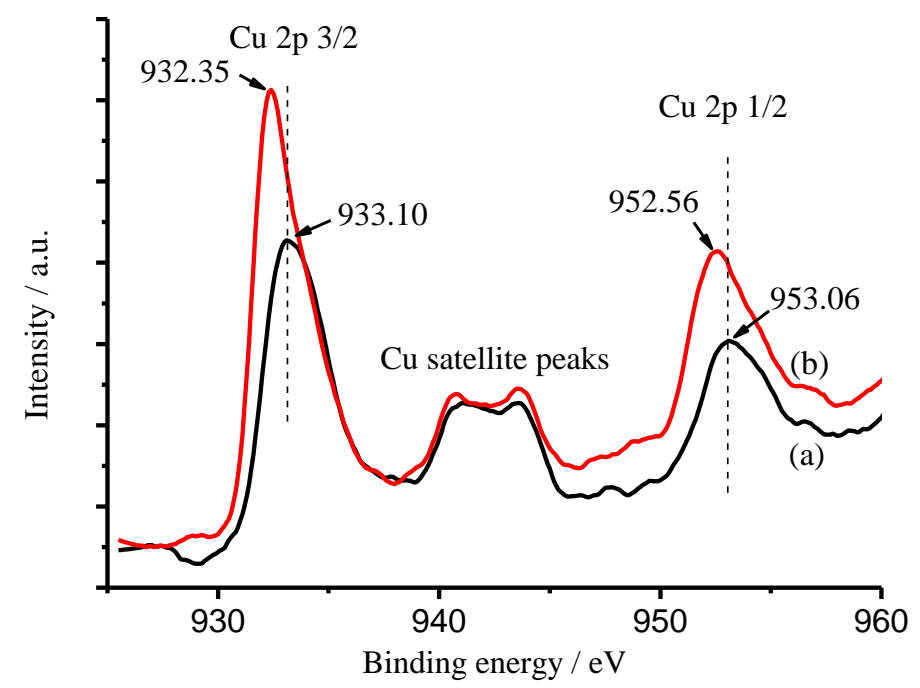

Figure 15. High-resolution XPS spectra of $\mathrm{Cu}$ component in the $\mathrm{CuFe}_{2} \mathrm{O}_{4}$ sample before (a) and after (b) it was immersed in $100 \mathrm{mg} / \mathrm{L} \mathrm{NH}_{3}-\mathrm{N}$ solution, respectively.

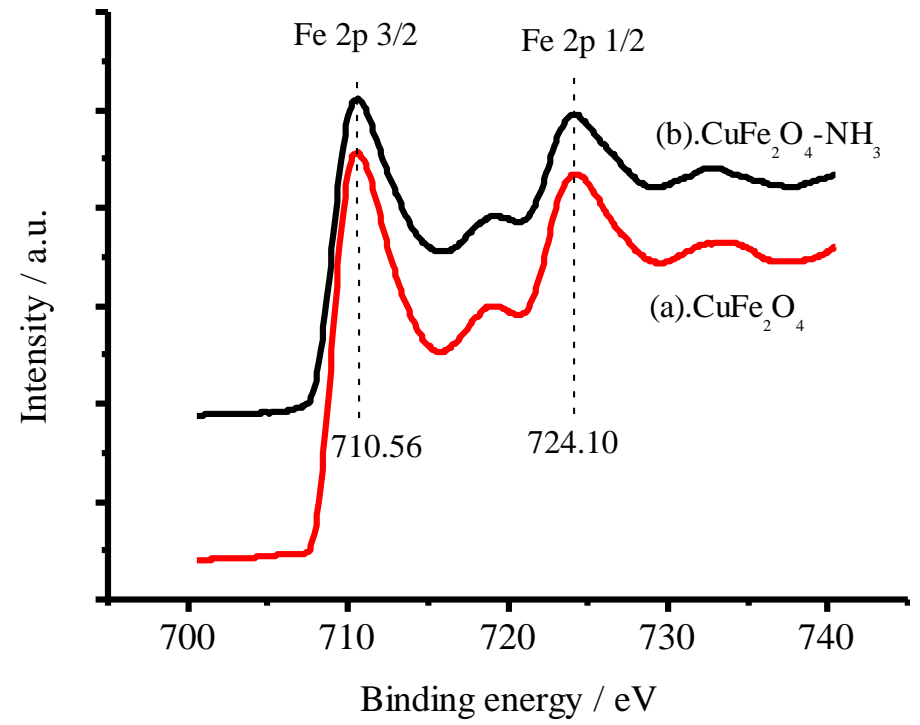

Figure 16. High-resolution XPS spectra of $\mathrm{Fe} 2 \mathrm{p}$ in the $\mathrm{CuFe}_{2} \mathrm{O}_{4}$ sample before (a) and after (b) adsorbing ammonia.

\subsection{Reaction Mechanism}

The surface photovoltage spectroscopy (SPV) was utilized to explore the transfer of the photo-generated holes and photo-generated electrons in order to elucidate the degradation mechanism of ammonia. As known, the surface photovoltage is defined as the illumination-induced change in the surface potential [49], being equal to the difference between the surface potential under illumination and the surface potential in dark given by Equation (2)

$$
\mathrm{SPV}=\mathrm{Vs}_{(\mathrm{ill})}-\mathrm{Vs}_{(\text {dark })}
$$

As far as the band-to-band transitions are concerned, a positive response of SPV means that the photo-generated holes move to the irradiation side of the sample, whereas the photo-generated electrons move into the bulk of the sample [50,51]. That is, the semiconductor material is an n-type semiconductor in this case. On the contrary, a negative response represents a p-type semiconductor. In the present case, the SPV responses measured for the $\mathrm{CuFe}_{2} \mathrm{O}_{4}$ sample were shown in Figure 17. 


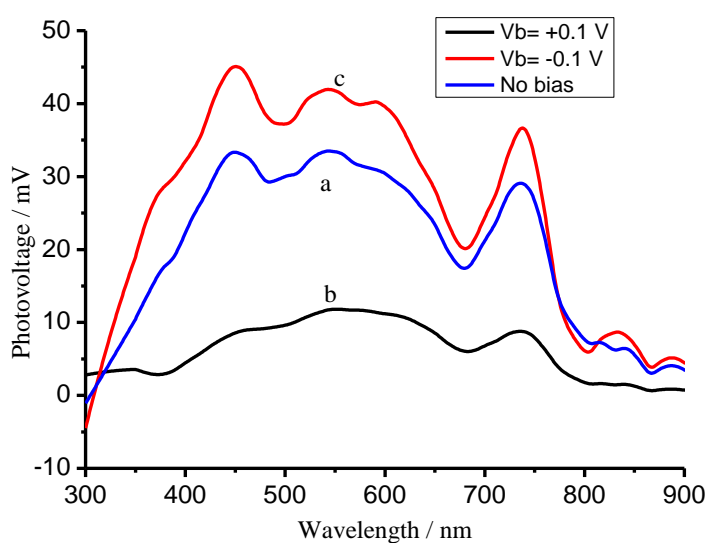

Figure 17. SPV spectra of the $\mathrm{CuFe}_{2} \mathrm{O}_{4}$ sample biased by an external electrical field at zero (a), $+0.1 \mathrm{~V}(\mathbf{b})$ and $-0.1 \mathrm{~V}$ (c).

Curve (a) in Figure 17 presents a positive response under incident light illumination, suggesting that the photo-generated holes move to the illuminated surface of the $\mathrm{CuFe}_{2} \mathrm{O}_{4}$ sample. Applying a positive bias of $0.1 \mathrm{~V}$ to the $\mathrm{CuFe}_{2} \mathrm{O}_{4}$ sample suppressed the holes moving to the surface, resulting in a decreased SPV response (b); whereas a negative bias of $0.1 \mathrm{~V}$ promoted the holes moving to the surface, leading to an increased SPV response (c). It can be concluded from these facts that the $\mathrm{CuFe}_{2} \mathrm{O}_{4}$ material is an n-type semiconductor in the case [52,53]. The XPS valence band spectra for the $\mathrm{CuFe}_{2} \mathrm{O}_{4}$ and NG semiconductor materials have been determined as shown in Figure 18A,B. The valence bands are equal to $1.7 \mathrm{eV}$ and $1.4 \mathrm{eV}$ for $\mathrm{CuFe}_{2} \mathrm{O}_{4}$ and NG [54], respectively. The conduction bands are equal to $0.2 \mathrm{eV}$ and $-0.1 \mathrm{eV}$ for $\mathrm{CuFe}_{2} \mathrm{O}_{4}$ and $\mathrm{NG}$, respectively, based on their measurements of band gaps.
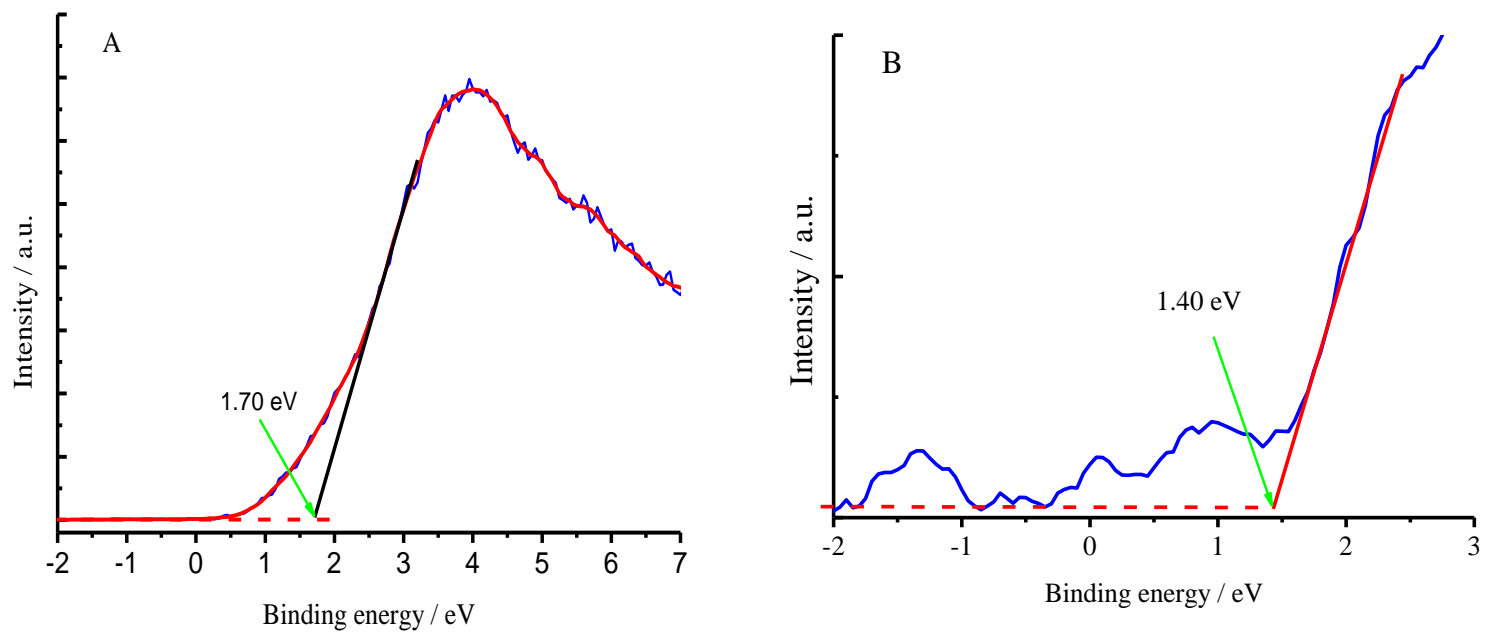

Figure 18. XPS valence band spectra of $\mathrm{CuFe}_{2} \mathrm{O}_{4} / \mathrm{NG}(\mathbf{A})$ and $\mathrm{NG}(\mathbf{B})$.

UV-visible near-infrared diffuse reflectance spectrum of NG sheets has been measured as shown in Figure 19. As seen, the absorption edge of NG sheets extended to near-infrared region, the insert indicated a direct band gap of $1.50 \mathrm{eV}$ for the as-synthesized NG sheets, corresponding to $826 \mathrm{~nm}$ near-infrared incident light. As Eda and Chai have postulated that isolated sp2 nanodomains are likely to exhibit quantum confinement-induced semiconducting behavior [55,56]. The local energy gaps of $\pi-\pi^{*}$ transition then vary depending on the size, shape and fraction of these sp2 domains. The smaller this sp2 domain, the higher the outcome of the energy gap [53]. The calculated energy gap between $\mathrm{HOMO}$ and LUMO for a cluster of 37 rings is $\sim 2 \mathrm{eV}$, and this energy gap progressively increases to $\sim 7 \mathrm{eV}$ for a single benzene ring [57]. Therefore, it is reasonable that the as-synthesized NG sheets work as a semiconductor with a band gap of $1.50 \mathrm{eV}$ in the present case. The conduction band of NG 
sheets can thereby be estimated as $-0.10 \mathrm{eV}$ based on its band gap of $1.50 \mathrm{eV}$ and valence band of $1.40 \mathrm{eV}$ measured in Figure 18B.

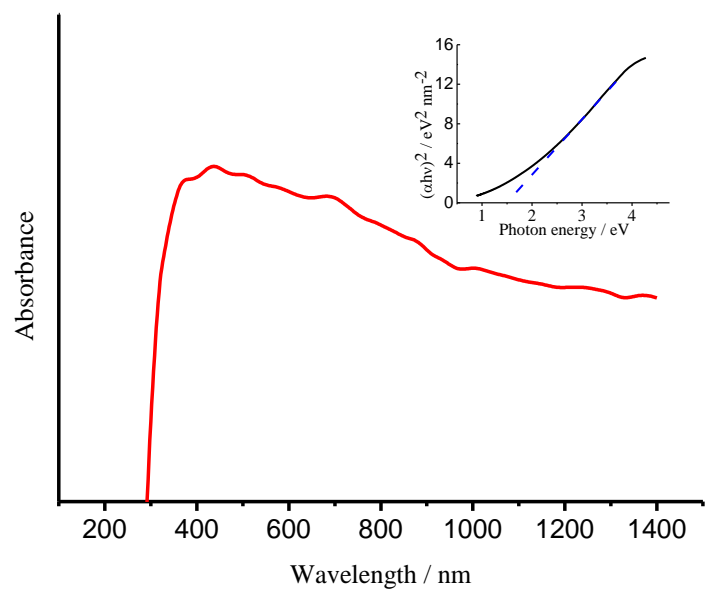

Figure 19. UV-visible near-infrared diffuse reflectance spectrum of the NG sample. Tauc-plots for the direct band-gaps of the NG sample.

Under consideration of the standard electrodes $\left(\mathrm{E}^{0}\right.$ for $\mathrm{N}_{2} / \mathrm{NH}_{3}$ redox is $0.057 \mathrm{~V}$ vs. $\mathrm{NHE}, \mathrm{E}^{0}$ for $\mathrm{O}_{2} / \mathrm{H}_{2} \mathrm{O}$ is $1.23 \mathrm{~V}$ vs. NHE), a Z-scheme mechanism can be suggested as demonstrated in Scheme $1[2,8]$.

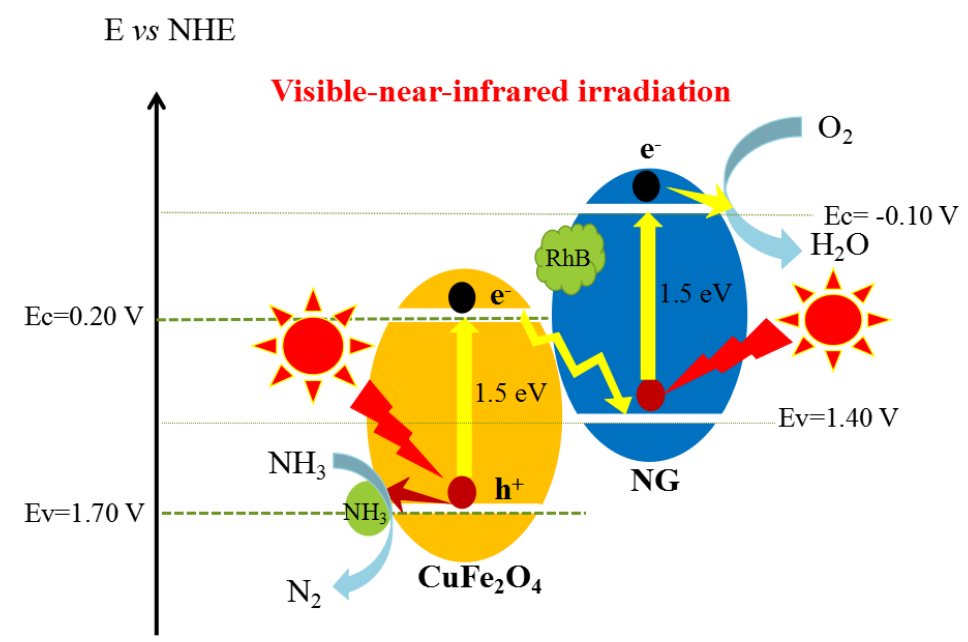

Scheme 1. Z-scheme photocatalytic mechanism of $\mathrm{CuFe}_{2} \mathrm{O}_{4} / \mathrm{NG}$. The photo-generated holes leave on $\mathrm{CuFe}_{2} \mathrm{O}_{4}$ to oxidize $\mathrm{NH}_{3}$ to $\mathrm{N}_{2}$, while the photo-generated electrons on the conduction band of $\mathrm{CuFe}_{2} \mathrm{O}_{4}$ flow to NG sheets along the $\mathrm{Z}$-scheme configuration to reduce $\mathrm{O}_{2}$ molecules under visible-near-infrared light irradiation.

As mentioned previously, $\mathrm{NH}_{3}$ molecules were selectively adsorbed on the $\mathrm{CuFe}_{2} \mathrm{O}_{4}$ component, while RhB molecules were dominantly adsorbed on the NG sheets by $\pi-\pi$ interaction. Therefore, $\mathrm{NH}_{3}$ molecules were oxidized by photo-generated holes on the valence band of copper ferrite to $\mathrm{N}_{2}$.

$$
2 \mathrm{NH}_{3}+6 \mathrm{~h}^{+}=\mathrm{N}_{2}+6 \mathrm{H}^{+}
$$

At the same time, photo-generated electrons reduce $\mathrm{O}_{2}$ dissolved in solution to $\mathrm{H}_{2} \mathrm{O}_{2}$ through $\mathrm{O}_{2}{ }^{-}$. first, then continue to reduce $\mathrm{H}_{2} \mathrm{O}_{2}$ to $\mathrm{H}_{2} \mathrm{O}$ [58].

$$
\begin{gathered}
\mathrm{O}_{2}+\mathrm{e}^{-}=\mathrm{O}_{2}{ }^{-} \cdot \\
\mathrm{O}_{2}{ }^{-}+2 \mathrm{H}^{+}+\mathrm{e}^{-}=\mathrm{H}_{2} \mathrm{O}_{2}
\end{gathered}
$$




$$
\mathrm{H}_{2} \mathrm{O}_{2}+2 \mathrm{H}^{+}+2 \mathrm{e}^{-}=2 \mathrm{H}_{2} \mathrm{O}
$$

Thus, the overall photocatalytic reaction can be formulated as follows in Scheme 1.

$$
2 \mathrm{NH}_{3}+3 / 2 \mathrm{O}_{2}=\mathrm{N}_{2}+3 \mathrm{H}_{2} \mathrm{O}
$$

\section{Experimental Section}

\subsection{Synthetic Procedures}

\subsubsection{Synthesis of N-Doped Graphene}

Hummers' method was initially adopted to synthesize graphene oxide (GO) as our group has previously synthesized [59] and NG was synthesized as the reference [25]. The as-synthesized GO $(0.1000 \mathrm{~g})$ was ultrasonically dispersed in $25.0 \mathrm{~mL}$ of deionized water. Urea (30.0000 g) was dissolved in $25.0 \mathrm{~mL}$ of deionized water under stirring. The urea solution was added dropwise to the GO suspension solution under stirring. Subsequently, deionized water of $10 \mathrm{~mL}$ was added in the mixture and ultrasonicated for $2 \mathrm{~h}$. After that, the mixture was transferred to a Teflon-lined stainless-steel autoclave with a volume of $60 \mathrm{~mL}$, sealed and heated to $170^{\circ} \mathrm{C}$ for $12 \mathrm{~h}$ to form NG. Finally, the resulting product was filtered, washed and dried in a vacuum chamber for use.

\subsubsection{Synthesis of $\mathrm{CuFe}_{2} \mathrm{O}_{4} / \mathrm{NG}$}

A one-step hydrothermal route has been used for preparing $\mathrm{CuFe}_{2} \mathrm{O}_{4} / \mathrm{NG}$ samples [60]. $\mathrm{Cu}\left(\mathrm{NO}_{3}\right)_{2} \cdot 3 \mathrm{H}_{2} \mathrm{O}(1.2080 \mathrm{~g}, 0.005 \mathrm{~mol})$ and $\mathrm{Fe}\left(\mathrm{NO}_{3}\right)_{3} \cdot 9 \mathrm{H}_{2} \mathrm{O}(4.0400 \mathrm{~g}, 0.01 \mathrm{~mol})$ were separately dissolved in $10.0 \mathrm{~mL}$ of deionized water. NG $\left(0.072 \mathrm{~g}, 6.0 \%\right.$ of the $\mathrm{CuFe}_{2} \mathrm{O}_{4}$ mass $)$ was dispersed in $10.0 \mathrm{~mL}$ of deionized water by an ultrasonic vibrator. The $\mathrm{Cu}$ (II) and $\mathrm{Fe}(\mathrm{III})$ solutions were added to NG suspension solution under stirring. $\mathrm{NaOH}(1.6 \mathrm{~g}, 0.04 \mathrm{~mol})$ was dissolved in $10.0 \mathrm{~mL}$ of deionized water, and this solution was added dropwise to the mixed suspension solution described above under continuous stirring. Deionized water was also added to the suspension to obtain a final volume of $60 \mathrm{~mL}$. The suspension solution was then transferred to a $100 \mathrm{~mL}$ Teflon-lined stainless-steel autoclave that was subsequently sealed and maintained at $180{ }^{\circ} \mathrm{C}$ for $10 \mathrm{~h}$. The solution was cooled to room temperature and filtered to obtain $\mathrm{CuFe}_{2} \mathrm{O}_{4} / \mathrm{NG}$ precipitates. The $\mathrm{CuFe}_{2} \mathrm{O}_{4}$ nanoparticles can be formed by reaction Equation (4). The products were rinsed thrice with water to remove excess $\mathrm{NaOH}$ and other electrolytes and dried at $60^{\circ} \mathrm{C}$ in a vacuum chamber for use.

$$
\mathrm{Cu}\left(\mathrm{NO}_{3}\right)_{2}+2 \mathrm{Fe}\left(\mathrm{NO}_{3}\right)_{3}+8 \mathrm{NaOH}=\mathrm{CuFe}_{2} \mathrm{O}_{4}+8 \mathrm{NaNO}_{3}+4 \mathrm{H}_{2} \mathrm{O}
$$

\subsection{Photovoltage Characterization}

Surface photovoltage spectra were recorded using a lock-in amplifier (SR830, Stanford Research Systems, Sunnyvale, CA, USA). The measurement system was composed of a $500 \mathrm{~W}$ xenon lamp, a monochromator (SBP500, Zolix Instruments Co., Ltd., Beijing China), a lock-in amplifier with a light chopper (SR540, Stanford Research Systems, Sunnyvale, CA, USA), and a sample chamber. The xenon lamp emitted incident photons with various wavelengths, which then passed through the monochromator to provide monochromatic light. The light was chopped with a frequency of $23 \mathrm{~Hz}$, and its intensity depended on the spectral energy distribution of the lamp. The monochromator and the lock-in amplifier were controlled by a computer. The input resistance of the lock-in amplifier was set as $10 \mathrm{M} \Omega$. SPV spectra were recorded by scanning from low to high photon energy. A UV-cutoff filter $(\lambda>420 \mathrm{~nm})$ was employed at incident photon energy hv $<2.14 \mathrm{eV}(\lambda>580 \mathrm{~nm})$ to remove the frequency and double the amount of light generated by the grating monochromator (doubled frequency of $\lambda>580 \mathrm{~nm}$ ). The system was calibrated by a DSI200 UV-enhanced silicon detector to eliminate possible phase shift not correlated with the SPV response; thus, any phase retardation reflected the kinetics of SPV response [61]. 


\subsection{Molecular Recognition and Selective Photocatalysis}

Photocatalytic experiments were conducted under visible-near-infrared irradiation $(\lambda>400 \mathrm{~nm})$. A $300 \mathrm{~W}$ UV-visible lamp (OSRAM, Munich, Germany) was used as a light source. Photocatalytic degradation was performed in a $100 \mathrm{~mL}$ beaker at room temperature $\left(25 \pm 2{ }^{\circ} \mathrm{C}\right)$. The distance between the lamp and test solution was approximately $10 \mathrm{~cm}$, and the wall of the beaker was shielded from surrounding light by aluminum foil. Visible-near-infrared light was allowed to pass through a $\lambda>400 \mathrm{~nm}$ cut-off filter covering the window of the beaker; this filter absorbed UV light and allowed visible-near-infrared light of $\lambda>400 \mathrm{~nm}$ to pass through. In a typical photocatalytic experiment, $50 \mathrm{~mL}$ of test solution was used. The $\mathrm{NH}_{3}$ solutions were prepared according to the desired concentrations, and the $\mathrm{CuFe}_{2} \mathrm{O}_{4} / \mathrm{NG}$ catalyst of $0.1 \mathrm{~g}$ was used for the photocatalytic experiments. $\mathrm{NaHCO}_{3}-\mathrm{Na}_{2} \mathrm{CO}_{3}(0.1 \mathrm{~mol} / \mathrm{L})$ buffer was used to control the $\mathrm{pH}$ of the test solutions. For the selective photocatalytic degradation, the $\mathrm{CuFe}_{2} \mathrm{O}_{4} / \mathrm{NG}$ catalyst of $0.1 \mathrm{~g}$ was immersed in $\mathrm{NH}_{3}-\mathrm{RhB}$ mixed solution for $2 \mathrm{~h}$ first, then the visible-near-infrared light source was turned on for the photocatalytic tests.

A double-beam TU-1901 spectrophotometer (PGENERAL Instrument Limited-liability Company, Beijing, China) was used to determine the concentration of $\mathrm{NH}_{3}$ by reaction with Nessler reagent during the photocatalytic process. Nessler reagent is an alkaline solution of dipotassium tetraiodomercurate(II), this reagent was prepared by dissolving $10 \mathrm{~g}$ of $\mathrm{HgI}_{2}$ and $7 \mathrm{~g}$ of $\mathrm{KI}$ in water, adding to $\mathrm{NaOH}$ solution ( $16 \mathrm{~g} \mathrm{NaOH}$ in $50 \mathrm{~mL}$ of water), and then diluting with deionized water to $100 \mathrm{~mL}$. The reagent was stored in dark bottles and diluted properly before analysis. $\mathrm{NH}_{3}$ reacts with this reagent to yield colored solutions via Reaction (2) previously. As the absorbance of the solutions showed a maximum value at $392 \mathrm{~nm}$, the absorbance was measured at the wavelength of $392 \mathrm{~nm}$.

The procedures for the stability tests are follows: The $\mathrm{CuFe}_{2} \mathrm{O}_{4} / \mathrm{NG}$ catalyst was sunk by a magnetic field outside due to the $\mathrm{CuFe}_{2} \mathrm{O}_{4}$ magnetism after the last test finished. And then, the supernatant solution tested was poured out, the solid catalyst was kept in. Finally, a $50 \mathrm{~mL}$ fresh $\mathrm{NH}_{3}$ solution was poured into the reactor. Subsequently, the next test was carried out again.

\section{Conclusions}

The composite photocatalyst composed of copper ferrite and $\mathrm{N}$-doped graphene enables to recognize ammonia from $\mathrm{NH}_{3}-\mathrm{RhB}$ mixed solution. The measurements of gas chromatography show that the composite photocatalyst oxidizes $\mathrm{NH}_{3}$ selectively to non-toxic $\mathrm{N}_{2}$ under visible near-infrared light irradiation, thereby fulfilling the removal of nitrogen, the effect solar use and purification of water. The mechanism studies indicate that the photo-generated electrons flow to $\mathrm{N}$-doped graphene following the $\mathrm{Z}$-scheme configuration to reduce $\mathrm{O}_{2}$ dissolved in solution.

Supplementary Materials: The following are available online at http:/ / www.mdpi.com/2073-4344/8/10/405/s1, Figure S1: Blank test. (a) visible-near-infrared irradiation without the photocatalyst; (b) $0.1 \mathrm{~g} \mathrm{CuFe}_{2} \mathrm{O}_{4} / \mathrm{NG}_{\text {catalyst }}$ used in solution without irradiation; (c) $0.1 \mathrm{~g} \mathrm{CuFe}_{2} \mathrm{O}_{4} / \mathrm{NG}$ catalyst used in solution under visible-near-infrared irradiation. The solution used is a $50 \mathrm{~mL}$ solution containing $100 \mathrm{mg} / \mathrm{L}$ ammonia-nitrogen at $\mathrm{pH}=9.5$. Figure S2: Effects of NG percentage on the photocatalytic activity of the as-prepared $\mathrm{CuFe}_{2} \mathrm{O}_{4} / \mathrm{NG}$ photocatalyst. $0.1 \mathrm{~g}$ photocatalyst in $50 \mathrm{~mL}$ solution at $\mathrm{pH} 9.5$ containing $100 \mathrm{mg} / \mathrm{L}$ ammonia-nitrogen. Figure S3: Photocatalytic degradation of ammonia using different catalysts: $\mathrm{CuFe}_{2} \mathrm{O}_{4} / \mathrm{NG}(\mathrm{a}), \mathrm{CuFe}_{2} \mathrm{O}_{4} / \mathrm{rGO}$ (b), and bare $\mathrm{CuFe}_{2} \mathrm{O}_{4}$ (c) in $100 \mathrm{mg} / \mathrm{L}$ ammonia-N solution, respectively. The catalyst of $0.1 \mathrm{~g}$ was added in $50 \mathrm{~mL}$ solution containing $100 \mathrm{mg} / \mathrm{L}$ ammonia-N with $\mathrm{pH} 9.5$ under visible-near-infrared irradiation. Figure S4: HRTEM image of the $\mathrm{CuFe}_{2} \mathrm{O}_{4} / \mathrm{NG}$ catalyst after it was tested for 6 runs. Figure S5: The absorption spectra of nitrate and nitrite standard solutions containing $1 \mathrm{mg} \mathrm{L}^{-1}$ of nitrogen. It is from the reference (see reference: D. L. Miles, C. Espejo, Comparison Between an Ultraviolet Spectrophotometric Procedure and the 2,4-Xylenol Method for the Determination of Nitrate in Ground waters of Low Salinity, Analyst, 1977,102, 104-109). Figure S6: The calibration curve of $\mathrm{NO}_{3}{ }^{-}$in the concentration range of $0.2-5.0 \mathrm{mg} / \mathrm{L}$. Figure S7: The chemical structure of Rhodamine B.

Author Contributions: H.Z., Y.Z. and Q.-Q.G. conducted the experiments and collected the data. S.-Q.L. designed the experiments and reviewed the article. Z.-D.M. analyzed the data and discussed the results. L.L. wrote draft. All authors discussed the results and commented on the manuscript. 
Funding: This research was funded by the National Natural Science Foundation of China (Nos. 21576175, 51502187), the key industrial prospective program of Jiangsu Science and Technology Department (BE2015190), the Natural Science Foundation of Jiangsu Province of China (No. BK20141178), the General Program of the Natural Science Foundation of the Jiangsu Higher Education Institutions of China (No. 16KJB150036), the Earmarked Nanotechnology Fund of the Bureau of Science and Technology of Suzhou City (No. ZXG201429) and Collaborative Innovation Center of Technology and Material of Water Treatment.

Conflicts of Interest: The authors declare no conflict of interest.

\section{References}

1. Lee, J.; Park, H.; Choi, W. Selective photocatalytic oxidation of $\mathrm{NH}_{3}$ to $\mathrm{N}_{2}$ on platinized $\mathrm{TiO}_{2}$ in water. Environ. Sci. Technol. 2002, 36, 5462-5468. [CrossRef] [PubMed]

2. Hussain, S.; Hussain, S.; Waleed, A.; Tavakoli, M.M.; Wang, Z.; Yang, S.; Fan, Z.; Nadeem, M.A. Fabrication of $\mathrm{CuFe}_{2} \mathrm{O}_{4} / \alpha-\mathrm{Fe}_{2} \mathrm{O}_{3}$ Composite Thin Films on FTO Coated Glass and 3-D Nanospike Structures for Efficient Photoelectrochemical Water Splitting. ACS Appl. Mater. Interfaces 2016, 8, 35315-35322. [CrossRef] [PubMed]

3. Jing, P.; Li, J.; Pan, L.; Wang, J.; Sun, X.; Liu, Q. Efficient photocatalytic degradation of acid fuchsin in aqueous solution using separate porous tetragonal-CuFe ${ }_{2} \mathrm{O}_{4}$ nanotubes. J. Hazard. Mater. 2015, 284, $163-170$. [CrossRef] [PubMed]

4. Xu, H.; Wang, Y.; Zheng, L.; Duan, X.; Wang, L.; Yang, J.; Qian, Y. Preparation of polypyrrole-coated CuFe $\mathrm{O}_{4}$ and their improved electrochemical performance as lithium-ion anodes. J. Energy Chem. 2014, 23, 354-357. [CrossRef]

5. Zhang, H.; Gao, S.; Shang, N.; Wang, C.; Wang, Z. Copper ferrite-graphene hybrid: A highly efficient magnetic catalyst for chemoselective reduction of nitroarenes. RSC Adv. 2014, 4, 31328-31332. [CrossRef]

6. Fu, Y.; Chen, Q.; He, M.; Wan, Y.; Sun, X.; Xia, H.; Wang, X. High photocatalytic activity of magnetically separable manganese ferrite-graphene heteroarchitectures. Ind. Eng. Chem. Res. 2012, 51, 725-731. [CrossRef]

7. Golshan, M.; Kakavandi, B.; Ahmadi, M.; Azizi, M. Photocatalytic activation of peroxymonosulfate by $\mathrm{TiO}_{2}$ anchored on cupper ferrite $\left(\mathrm{TiO}_{2} @ \mathrm{CuFe}_{2} \mathrm{O}_{4}\right)$ into 2,4-D degradation: Process feasibility, mechanism and pathway. J. Hazard. Mater. 2018, 359, 325-337. [CrossRef] [PubMed]

8. Li, Z.; Lyu, J.; Sun, K.; Ge, M. Construction of magnetic $\mathrm{AgBr} / \mathrm{Cu} / \mathrm{CuFe} \mathrm{O}_{4}$ Z-scheme photocatalyst with improved photocatalytic performance. Mater. Lett. 2018, 214, 257-260. [CrossRef]

9. Zhou, T.; Zhang, G.; Ma, P.; Qiu, X.; Zhang, H.; Yang, H.; Liu, G. Novel magnetically separable $\mathrm{Ag}_{3} \mathrm{PO}_{4} @ \mathrm{CuFe}_{2} \mathrm{O}_{4}$ micro-nanocomposite with highly enhanced visible-light-driven photocatalytic activity. Mater. Lett. 2018, 210, 271-274. [CrossRef]

10. Wang, L.; Hu, G.; Wang, Z.; Wang, B.; Song, Y.; Tang, H. Highly efficient and selective degradation of methylene blue from mixed aqueous solution by using monodisperse $\mathrm{CuFe}_{2} \mathrm{O}_{4}$ nanoparticles. RSC Adv. 2015, 5, 73327-73332. [CrossRef]

11. Giovannetti, R.; Rommozzi, E.; Zannotti, M.; D'Amato, C.A. Recent Advances in Graphene Based $\mathrm{TiO}_{2}$ Nanocomposites $\left(\mathrm{GTiO}_{2} \mathrm{Ns}\right)$ for Photocatalytic Degradation of Synthetic Dyes. Catalysts 2017, 7, 305. [CrossRef]

12. Li, W.; Zhang, Y.; Tian, G.; Wang, L.; Tian, J.; Bu, Y. Fabrication of graphene-modified nano-sized red phosphorus for enhanced photocatalytic performance. J. Mol. Catal. A Chem. 2016, 423, 356-364. [CrossRef]

13. Tian, H.; Wan, C.; Xue, X.; Hu, X.; Wang, X. Effective Electron Transfer Pathway of the Ternary TiO $2 / \mathrm{RGO} / \mathrm{Ag}$ Nanocomposite with Enhanced Photocatalytic Activity under Visible Light. Catalysts 2017, 7, 156. [CrossRef]

14. Zabihi, F.; Ahmadian-Yazdi, M.R.; Eslamian, M. Photocatalytic Graphene-TiO 2 Thin Films Fabricated by Low-Temperature Ultrasonic Vibration-Assisted Spin and Spray Coating in a Sol-Gel Process. Catalysts 2017, 7, 136. [CrossRef]

15. Arcibar-Orozco, J.A.; Giannakoudakis, D.A.; Bandosz, T.J. Copper hydroxyl nitrate/graphite oxide composite as superoxidant for the decomposition/mineralization of organophosphate-based chemical warfare agent surrogate. Adv. Mater. Interfaces 2015, 2, 1-9. [CrossRef]

16. Su, P.; Iwase, K.; Nakanishi, S.; Hashimoto, K.; Kamiya, K. Nickel-nitrogen-modified graphene: An efficient electrocatalyst for the reduction of carbon dioxide to carbon monoxide. Small 2016, 12, 6083-6089. [CrossRef] [PubMed] 
17. Stankovich, S.; Dikin, D.A.; Dommett, G.H.B.; Kohlhaas, K.M.; Zimney, E.J.; Stach, E.A.; Piner, R.D.; Nguyen, S.B.T.; Ruoff, R.S. Graphene-based composite materials. Nature 2006, 442, 282-286. [CrossRef] [PubMed]

18. Dai, L.; Xue, Y.; Qu, L.; Choi, H.J.; Baek, J.B. Metal-free catalysts for oxygen reduction reaction. Chem. Rev. 2015, 115, 4823-4892. [CrossRef] [PubMed]

19. Wang, H.; Maiyalagan, T.; Wang, X. Review on recent progress in nitrogen-doped graphene: Synthesis, characterization, and its potential applications. ACS Catal. 2012, 2, 781-794. [CrossRef]

20. Chang, D.W.; Baek, J.B. Nitrogen-Doped Graphene for Photocatalytic Hydrogen Generation. Chem. Asian J. 2016, 11, 1125-1137. [CrossRef] [PubMed]

21. Feng, L.; Chen, Y.; Chen, L. Easy-to-operate and low-temperature synthesis of gram-scale nitrogen-doped graphene and its application as cathode catalyst in microbial fuel cells. ACS Nano 2011, 5, 9611-9618. [CrossRef] [PubMed]

22. Ma, G.; Jia, R.; Zhao, J.; Wang, Z.; Song, C.; Jia, S.; Zhu, Z. Nitrogen-doped hollow carbon nanoparticles with excellent oxygen reduction performances and their electrocatalytic kinetics. J. Phys. Chem. C 2011, 115, 25148-25154. [CrossRef]

23. Rao, C.V.; Ishikawa, Y. Activity, selectivity, and anion-exchange membrane fuel cell performance of virtually metal-free nitrogen-doped carbon nanotube electrodes for oxygen reduction reaction. J. Phys. Chem. C 2012, $116,4340-4346$.

24. Shao, Y.; Zhang, S.; Engelhard, M.H.; Li, G.; Shao, G.; Wang, Y.; Lin, Y. Nitrogen-doped graphene and its electrochemical applications. J. Mater. Chem. 2010, 20, 7491-7496. [CrossRef]

25. Wu, J.; Zhang, D.; Wang, Y.; Hou, B. Electrocatalytic activity of nitrogen-doped graphene synthesized via a one-pot hydrothermal process towards oxygen reduction reaction. J. Power Sources 2013, 227, 185-190. [CrossRef]

26. Zheng, B.; Wang, J.; Wang, F.B.; Xia, X.H. Synthesis of nitrogen doped graphene with high electrocatalytic activity toward oxygen reduction reaction. Electrochem. Commun. 2013, 28, 24-26. [CrossRef]

27. Shen, Y.; Wu, Y.; Xu, H.; Fu, J.; Li, X.; Zhao, Q.; Hou, Y. Facile preparation of sphere-like copper ferrite nanostructures and their enhanced visible-light-induced photocatalytic conversion of benzene. Mater. Res. Bull. 2013, 48, 4216-4222. [CrossRef]

28. Li, Y.; Shen, J.; Hu, Y.; Qiu, S.; Min, G.; Song, Z.; Li, C. General flame approach to chainlike $\mathrm{MFe}_{2} \mathrm{O}_{4}$ spinel $(\mathrm{M}=\mathrm{Cu}, \mathrm{Ni}, \mathrm{Co}, \mathrm{Zn})$ nanoaggregates for reduction of nitroaromatic compounds. Ind. Eng. Chem. Res. 2015, 54, 9750-9757. [CrossRef]

29. Guo, T.; Dang, C.; Tian, S.; Wang, Y.; Cao, D.; Gong, Y.; Zhao, S.; Mao, R.; Yang, B.; Zhao, X. Persulfate enhanced photoelectrocatalytic degradation of cyanide using a $\mathrm{CuFe}_{2} \mathrm{O}_{4}$ modified graphite felt cathode. Chem. Eng. J. 2018, 347, 535-542. [CrossRef]

30. Gao, J.; Wu, S.; Han, Y.; Tan, F.; Shi, Y. 3D Mesoporous $\mathrm{CuFe}_{2} \mathrm{O}_{4}$ as a Catalyst for photo-Fenton Removal of Sulfonamide Antibiotics at Near Neutral pH. J. Colloid Interface Sci. 2018, 524, 409-416. [CrossRef] [PubMed]

31. Nasrallah, N.; Kebir, M.; Koudri, Z.; Trari, M. Photocatalytic reduction of Cr (VI) on the novel hetero-system $\mathrm{CuFe}_{2} \mathrm{O}_{4} / \mathrm{CdS}$. J. Hazard. Mater. 2011, 185, 1398-1404. [CrossRef] [PubMed]

32. Chen, P.; Xing, X.; Xie, H.; Sheng, Q.; Qu, H. High catalytic activity of magnetic $\mathrm{CuFe}_{2} \mathrm{O}_{4}$ / graphene oxide composite for the degradation of organic dyes under visible light irradiation. Chem. Phys. Lett. 2016, 660, 176-181. [CrossRef]

33. Fu, Y.; Chen, Q.; He, M.; Wan, Y.; Sun, X.; Xia, H.; Wang, X. Copper ferrite-graphene hybrid: A multifunctional heteroarchitecture for photocatalysis and energy storage. Ind. Eng. Chem. Res. 2012, 5, 11700-11709. [CrossRef]

34. Zhu, X.; Castleberry, S.R.; Nanny, M.A.; Butler, E.C. Effects of $\mathrm{pH}$ and catalyst concentration on photocatalytic oxidation of aqueous ammonia and nitrite in titanium dioxide suspensions. Environ. Sci. Technol. 2005, 39, 3784-3791. [CrossRef] [PubMed]

35. Miles, D.L.; Espejo, C. Comparison between an ultraviolet spectrophotometric procedure and the 2,4-xylenol method for the determination of nitrate in groundwaters of low salinity. Analyst 1977, 102, 104-109. [CrossRef]

36. Xiao, B.; Liu, S.Q. Photocatalytic oxidation of ammonia via an activated carbon-nickel ferrite hybrid catalyst under visible light irradiation. Acta Phys. Chim. Sin. 2014, 30, 1697-1705. 
37. Silva, M.D.P.; Silva, F.C.; Sinfrônio, F.S.M.; Paschoal, A.R.; Silva, E.N.; Paschoal, C.W.A. The effect of cobalt substitution in crystal structure and vibrational modes of $\mathrm{CuFe}_{2} \mathrm{O}_{4}$ powders obtained by polymeric precursor method. J. Alloys Compd. 2014, 584, 573-580. [CrossRef]

38. Ujike, T.; Tominaga, Y. Raman spectral analysis of liquid ammonia and aqueous solution of ammonia. J. Raman Spectrosc. 2002, 33, 485-493. [CrossRef]

39. Fang, W.; Shan, X.; Li, Z.; Sun, C.; Li, Z.; Men, Z.; Fan, L. Stimulated resonance Raman scattering of Rhodamine B. Optik 2012, 123, 1845-1846. [CrossRef]

40. Geiman, I.; Leona, M.; Lombardi, J.R. Application of raman spectroscopy and surface-enhanced raman scattering to the analysis of synthetic dyes found in ballpoint pen inks. J. Forensic Sci. 2009, 54, 947-952. [CrossRef] [PubMed]

41. Sun, C.H.; Wang, M.L.; Feng, Q.; Liu, W.; Xu, C.X. Surface-enhanced Raman scattering (SERS) study on rhodamine B adsorbed on different substrates. Russ. J. Phys. Chem. A 2015, 89, 291-296. [CrossRef]

42. Wang, X.; Weng, Q.; Liu, X.; Wang, X.; Tang, D.M.; Tian, W.; Zhang, C.; Yi, W.; Liu, D.; Bando, Y.; et al. Atomistic origins of high rate capability and capacity of n-doped graphene for lithium storage. Nano Lett. 2014, 14, 1164-1171. [CrossRef] [PubMed]

43. He, L.; Jing, L.; Luan, Y.; Wang, L.; Fu, H. Enhanced visible activities of $\alpha-\mathrm{Fe}_{2} \mathrm{O}_{3}$ by coupling N-doped graphene and mechanism insight. ACS Catal. 2014, 4, 990-998. [CrossRef]

44. Varghese, N.; Ghosh, A.; Voggu, R.; Ghosh, S.; Rao, C. Selectivity in the interaction of electron donor and acceptor molecules with graphene and single-walled carbon nanotubes. J. Phys. Chem. C 2009, 113, 16855-16859. [CrossRef]

45. Feng, S.; Santos, M.C.; Carvalho, B.R.; Lv, R.; Li, Q.; Fujisawa, K.; Elías, A.L.; Lei, Y.; Perea-López, N.; Endo, M.; et al. Ultrasensitive molecular sensor using N-doped graphene through enhanced Raman scattering. Sci. Adv. 2016, 2, e1600322. [CrossRef] [PubMed]

46. Hendrickson, D.N.; Hollander, J.M.; Jolly, W.L. Nitrogen ls electron binding energies. Correlations with molecular orbital calculated nitrogen charges. Inorg. Chem. 1969, 8, 2642-2647. [CrossRef]

47. Battistoni, C.; Mattogno, G.; Paparazzo, E. An XPS and auger study of some polynuclear copper compounds. Inorg. Chim. Acta 1985, 102, 1-3. [CrossRef]

48. Zhang, W.; Quan, B.; Lee, C.; Park, S.K.; Li, X.; Choi, E.; Diao, G.; Piao, Y. One-step facile solvothermal synthesis of copper ferrite-graphene composite as a high-performance supercapacitor material. ACS Appl. Mater. Interfaces 2015, 7, 2404-2414. [CrossRef] [PubMed]

49. Kronik, L.; Shapira, Y. Surface photovoltage phenomena: Theory, experiment, and applications. Surf. Sci. Rep. 1999, 37, 1-206. [CrossRef]

50. Fan, H.; Jiang, T.; Li, H.; Wang, D.; Wang, L.; Zhai, J.; He, D.; Wang, P.; Xie, T. Effect of BiVO 4 crystalline phases on the photoinduced carriers behavior and photocatalytic activity. Phys. Chem. C 2012, 116, 2425-2430. [CrossRef]

51. Zhang, Z.; Yates, J.T., Jr. Band Bending in Semiconductors: Chemical and Physical Consequences at Surfaces and Interfaces. Chem. Rev. 2012, 112, 5520-5551. [CrossRef] [PubMed]

52. Li, C.; Jiao, C.Q.; Sun, Z.G.; Chen, K.; Wang, C.L.; Zhu, Y.Y.; Zhu, J.; Zhao, Y.; Zheng, M.J.; Sun, S.H.; et al. Synthesis, structures and surface photovoltage properties of four novel metal phosphonateswith a 3D supramolecular structure. CrystEngComm 2012, 14, 5479-5486. [CrossRef]

53. Zheng, M.J.; Zhu, Y.Y.; Sun, Z.G.; Zhu, J.; Jiao, C.Q.; Chu, W.; Sun, S.H.; Tian, H. Synthesis, crystal structures, and surface photovoltage properties of four new metal diphosphonates based on the mixed ligands. CrystEngComm 2013, 15, 1445-1453. [CrossRef]

54. Yang, M.L.; Zhang, N.; Lu, K.Q.; Xu, Y.J. Insight into the role of size modulation on tuning the band gap and photocatalytic performance of semiconducting nitrogen-doped graphene. Langmuir 2017, 33, 3161-3169. [CrossRef] [PubMed]

55. Eda, G.; Lin, Y.Y.; Mattevi, C.; Yamaguchi, H.; Chen, H.A.; Chen, I.S.; Chen, C.W.; Chhowalla, M. Blue photoluminescence from chemically derived graphene oxide. Adv. Mater. 2010, 22, 505-509. [CrossRef] [PubMed]

56. Putri, L.K.; Ng, B.J.; Ong, W.J.; Lee, H.W.; Chang, W.S.; Chai, S.P. Heteroatom nitrogen- and boron-doping as a facile strategy to improve photocatalytic activity of standalone reduced graphene oxide in hydrogen evolution. ACS Appl. Mater. Interfaces 2017, 9, 4558-4569. [CrossRef] [PubMed] 
57. Chen, C.W.; Robertson, J. Nature of disorder and localization in amorphous carbon. J. Non-Cryst. Solids 1998, 227-230, 602-606. [CrossRef]

58. Song, J.; Yan, L.; Duan, J.; Jing, C. $\mathrm{TiO}_{2}$ crystal facet-dependent antimony adsorption and photocatalytic oxidation. J. Colloid Interface Sci. 2017, 496, 522-530. [CrossRef] [PubMed]

59. Liu, S.Q.; Xiao, B.; Feng, L.R.; Zhou, S.S.; Chen, Z.G.; Liu, C.B.; Meng, Z.D. Graphene oxide enhances the Fenton-like photocatalytic activity of nickel ferrite for degradation of dyes under visible light irradiation. Carbon 2013, 64, 197-206. [CrossRef]

60. Zhao, Y.; He, G.; Dai, W.; Chen, H. High catalytic activity in the phenol hydroxylation of magnetically separable $\mathrm{CuFe}_{2} \mathrm{O}_{4}$-reduced graphene oxide. Ind. Eng. Chem. Res. 2014, 53, 12566-12574. [CrossRef]

61. Liu, S.; Zhu, X.; Zhou, Y.; Meng, Z.; Chen, Z.; Liu, C.; Chen, F.; Wu, Z.; Qian, J. Smart photocatalytic removal of ammonia through molecular recognition of zinc ferrite/reduced graphene oxide hybrid catalyst under visible-light irradiation. Catal. Sci. Technol. 2017, 7, 3210-3219. [CrossRef]

(C) 2018 by the authors. Licensee MDPI, Basel, Switzerland. This article is an open access article distributed under the terms and conditions of the Creative Commons Attribution (CC BY) license (http://creativecommons.org/licenses/by/4.0/). 